\title{
Paracrine regulation of growth hormone gene expression by gonadotrophin release in grass carp pituitary cells: functional implications, molecular mechanisms and signal transduction
}

\author{
Hong Zhou, Yonghua Jiang, Wendy K W Ko, Wensheng Li and Anderson O L Wong \\ Department of Zoology, University of Hong Kong, Pokfulam Road, Hong Kong SAR, People's Republic of China
}

(Requests for offprints should be addressed to A O L Wong; Email: olwong @ hkucc.hku.hk)

\begin{abstract}
Growth hormone $(\mathrm{GH})$ is known to stimulate luteinizing hormone $(\mathrm{LH})$ release via paracrine interactions between somatotrophs and gonadotrophs. However, it is unclear if $\mathrm{LH}$ can exert a reciprocal effect to modulate somatotroph functions. Here we examined the paracrine effects of LH on GH gene expression using grass carp pituitary cells as a cell model. LH receptors were identified in grass carp somatotrophs and their activation by human chorionic gonadotropin (hCG) increased 'steady-state' GH mRNA levels. Removal of endogenous LH by immunoneutralization using $\mathrm{LH}$ antiserum inhibited $\mathrm{GH}$ release and GH mRNA expression. GH secretagogues, including gonadotrophin releasing hormone $(\mathrm{GnRH})$, pituitary adenylate cyclase-activating polypeptide (PACAP) and apomorphine, were effective in elevating GH mRNA levels but these stimulatory actions were blocked by LH antiserum. In pituitary cells pretreated with actinomycin D, the half-life of GH mRNA was not affected by hCG but was enhanced by LH immunoneutralization. Treatment with LH antiserum also suppressed basal levels of mature GH mRNA and primary transcripts. hCG increased cAMP synthesis in carp pituitary cells and hCG-induced GH mRNA expression was mimicked by forskolin but suppressed by inhibiting adenylate cyclase and protein kinase A. Similarly, the stimulatory actions of hCG and forskolin on GH mRNA expression were blocked by inhibiting Janus kinase 2 (JAK2) and MAP kinase (MAPK), including P42/44MAPK and P38 MAPK. These results suggest that LH is essential for the maintenance of $\mathrm{GH}$ release, $\mathrm{GH}$ gene expression, and somatotroph responsiveness to $\mathrm{GH}$-releasing factors. The paracrine actions of $\mathrm{LH}$ on $\mathrm{GH}$ mRNA expression are mediated by a concurrent increase in $\mathrm{GH}$ gene transcription and GH mRNA turnover, probably through JAK2/MAPK coupled to the cAMP-dependent pathway.
\end{abstract}

Journal of Molecular Endocrinology (2005) 34, 415-432

\section{Introduction}

Growth hormone $(\mathrm{GH})$ is well documented to be an important pituitary hormone regulating body growth and metabolism. However, increasing evidence suggests that $\mathrm{GH}$ also plays a role in reproductive functions. Recently, GH has been proposed to be a 'cogonadotrophin' in mammals (Hull \& Harvey 2002). This idea is supported by the findings that correlative changes in GH secretion can be observed at various stages of the ovarian cycle, sexual maturation, pregnancy, and seasonal breeding (Hull \& Harvey 2000a,b). Furthermore, pathological conditions with gonadal deficiency (e.g. Turner's syndrome) tend to be associated with a drop in GH secretion, which can be partially rectified by steroid replacement (Wit et al. 1992). Gonadal steroids also modify the pulsatile pattern of GH release (Kerrigan \& Rogol 1992), probably by regulating gene expression of GH-releasing hormone (GHRH) in the arcuate nucleus (Zeitler et al. 1990) and somatostatin (SRIF) in the periventricular nucleus (Argente et al. 1990). In addition to these central actions, gonadotrophic and somatotrophic interactions can also occur at the pituitary level. In the rat, $\mathrm{GH}$ binding sites have been identified in gonadotrophs (Harvey et al. 1993) and basal secretion of luteinizing hormone $(\mathrm{LH})$ and/or folliclestimulating hormone (FSH) in vivo (Schemm et al. 1990) and in vitro (Tang et al. 1993) can be elevated by GH treatment. The stimulatory effects of gonadotrophin $(\mathrm{GTH})$-releasing hormone $(\mathrm{GnRH})$ on $\mathrm{LH}$ and $\mathrm{FSH}$ release, however, can be inhibited by GH immunoneutralization (Chandrashekar \& Bartke 1998). These findings, as a whole, raise the possibility that $\mathrm{GH}$ stimulates GTH secretion by local interactions between somatotrophs and gonadotrophs (Schwartz 2000). In this case, GH-induced GTH release regulates reproductive functions through GTH receptors coupled to the adenylate cyclase $(\mathrm{AC}) / \mathrm{cAMP} /$ protein kinase A (PKA) and phospholipase $\mathrm{C}$ (PLG)/inositol 1,4,5-triphosphate (IP3)/protein kinase $\mathrm{C}$ (PKG) cascades (Ascoli et al. 
2002). Functional coupling of GTH receptors with mitogen-activated protein kinases (MAPK) and phosphoinositol 3-kinase (PI3K) has also been reported recently (Seger et al. 2001, Carvalho et al. 2003). Given that the direct actions of GTH on GH release and synthesis at the pituitary level have not been examined, whether GTH can also act in a reciprocal manner to modify somatotroph functions is unclear.

The bony fish, or teleosts, are unique for the lack of a hypothalamo-hypophyseal portal blood system and the median eminence is functionally integrated into the anterior pituitary (Peter et al. 1990). In this case, the endocrine cells in the pars distalis are directly innervated by neurons from the hypothalamus. In addition to this structural modification in the brain-pituitary axis, a clear zonation of endocrine cells is also observed in the anterior pituitary of teleosts which is different from the random pattern of distribution found in mammals (Doerr-Schott 1980). In the pituitary of teleosts, e.g. grass carp (Wong et al. 1998a), lactotrophs are located exclusively in the rostral pars distalis (RPD) whereas the distribution of somatotrophs and gonadotrophs are restricted to the proximal pars distalis (PPD). In some species, e.g. tuna (Kagawa et al. 1998), gonadotrophs can also be found in the region along the external rim of the neurointermediate lobe (NIL). In bony fish studied to date, gonadotrophs always exhibit a patchy distribution in the PPD within a matrix formed by somatotrophs. Such a conserved pattern of anatomical relationship between these two cell types may suggest that paracrine interactions between somatotrophs and gonadotrophs also exist in fish. In salmons, it is well documented that $\mathrm{GH}$ also plays a role in the regulation of reproductive functions, including steroidogenesis, spermatogenesis, and oocyte maturation (LeGac 1993). In Cyprinids, e.g. white sucker (Stacey et al. 1984), a close correlation between GH and LH (or GTH-II) release can be noted during the period of sexual recrudescence and the spawning season. Recently, a similar correlation at the transcript level has been reported for the two hormones in gilthead seabream (Meiri et al. 2004). In the goldfish, the preovulatory LH surge occurs with a concurrent increase in GH release in vivo (Peter \& Yu 1997). This parallel increase in GH and $\mathrm{LH}$ secretion is particularly important for seasonal breeders with overlapping somatic growth and gonadal development during the reproductive cycle. This phenomenon has been largely attributed to the stimulatory effects of $\mathrm{GnRH}$ on $\mathrm{GH}$ and LH release at the pituitary level, e.g. in goldfish (Peter \& Yu 1997) and common carp (Lin et al. 1993). Whether local interactions between somatotrophs and gonadotrophs also contribute to the coordinated release of GH and LH in fish models is still unknown.

In this study, paracrine actions of LH on GH synthesis were examined in pituitary cells prepared from one-year-old $(1+)$ grass carps. The grass carp at this stage undergoes a rapid growth phase during the transition from juvenile to adult stage and represents a unique model for the studies of the mechanisms regulating GH synthesis and secretion in 'prepubertal' teleosts. Using a static incubation approach, the effects of exogenous LH on GH mRNA expression were tested in grass carp pituitary cells. The results of these studies were also confirmed by removal of endogenous LH using immunoneutralization. To characterize the role of $\mathrm{LH}$ in the responsiveness of somatotrophs to $\mathrm{GH}$ secretagogues, the stimulatory actions of known GHreleasing factors in fish on GH mRNA expression were tested either in the presence of exogenous LH or in the absence of endogenous LH caused by LH immunoneutralization. Parallel experiments were also conducted to study the effects of LH immunoneutralization on the clearance of GH mRNA and production of GH primary transcripts. To further elucidate the post-receptor signalling mechanisms mediating $\mathrm{LH}$ actions at the pituitary cell level, the effects of exogenous LH on GH mRNA expression were also tested in the presence of the inhibitors for the cAMP-, Janus kinase 2 (JAK2)-, MAPK-, and PI3K-dependent pathways respectively.

\section{Materials and methods}

\section{Animals}

One-year-old $(1+)$ Chinese grass carps (Ctenopharyngodon idellus) with body weights ranging from $1.5 \mathrm{~kg}$ to $2.0 \mathrm{~kg}$ were obtained from local markets and housed in well-aerated 200 litre aquaria under a $12 \mathrm{~h}$ light: $12 \mathrm{~h}$ darkness photoperiod at $18 \pm 2{ }^{\circ} \mathrm{C}$. Since the carps at this stage were 'prepubertal' (gonadosomatic index $\leq$ $0 \cdot 2 \%$ ) and sexual dimorphism was not apparent, fish of mixed sexes were used for the preparation of pituitary cell cultures. During the process, the fish were killed by anaesthesia in $0.05 \%$ MS222 (Sigma) followed by spinosectomy according to the regulations of animal use at the University of Hong Kong.

\section{Reagents and test substances}

Human chorionic gonadotropin (hGG), apomorphine (APO), and MDL12330A were obtained from Sigma (St Louis, MO, USA). Salmon gonadotrophin-releasing hormone $(\mathrm{GnRH})$ and ovine pituitary adenylate cyclase-activating polypeptide-38 (PACAP) were purchased from Phoenix Pharmaceuticals Inc. (Belmont, CA, USA). Forskolin, actinomycin D, H89, 3-isobutyl-1methylxanthine (IBMX), PD98059, SB202190, AG490 and wortmannin were from Calbiochem (San Diego, CA, USA). MEM Eagle, fetal bovine serum (FBS), trypsin, and antibiotic-antimycotic stock solution were obtained from GIBCO BRL Life Technology (Rockville, 
MA, USA). Forskolin, IBMX, H89, MDL12330A, PD98059, SB202190, AG490 and wortmannin were dissolved in DMSO to form $10 \mathrm{mM}$ stock solutions and stored frozen in small aliquots at $-80^{\circ} \mathrm{C}$. Stock solutions of peptide hormones, including hCG, GnRH, and PACAP, were prepared in a similar manner except that these peptides were dissolved in double-distilled deionized water at $1 \mathrm{mM}$ concentration. On the day of experiments, frozen stocks of test substances were diluted with culture medium to appropriate concentrations 30 min before adding to pituitary cells. Since APO can be easily oxidized in solution by prolonged storage, a $10 \mathrm{mM}$ stock was freshly prepared in DMSO $15 \mathrm{~min}$ prior to drug treatment. In these experiments, the final levels of DMSO were always below $0 \cdot 1 \%(\mathrm{v} / \mathrm{v})$ and had no effects on GH release and GH mRNA expression.

\section{Primary culture of grass carp pituitary cells}

Grass carp pituitary cells were prepared by the controlled trypsin/DNase II digestion method (Wong et al. 1998a) and cultured in 24-well clustered plates (Costar, Corning Inc., New York, NY, USA) at a seeding density of $\sim 2.5 \times 10^{6} \mathrm{cells} / \mathrm{ml} /$ well $(\sim 1.25 \times$ $10^{6}$ cells $/ 100 \mathrm{~mm}^{2}$ ) in carp MEM (MEM Eagle with $26 \mathrm{mM} \mathrm{NaHCO}_{3}, 25 \mathrm{mM}$ HEPES, 100 units $/ \mathrm{ml}$ penicillin, and $100 \mu \mathrm{g} / \mathrm{ml}$ streptomycin; pH 7.7) supplemented with 5\% FBS. The average cell yield was $\sim 8.2 \times 10^{6}$ cells/pituitary with a mean viability of $96 \cdot 5 \pm 0.5 \% \quad(n=14)$. Pituitary cells were routinely incubated overnight at $28{ }^{\circ} \mathrm{C}$ under $5 \% \mathrm{CO}_{2}$ to allow for the recovery of membrane receptors after trypsin digestion. On the following day, culture medium was replaced with serum-free carp MEM and drug treatment was initiated for the duration as indicated in individual experiments.

\section{Measurement of 'steady-state' GH mRNA}

After drug treatment, pituitary cells were dissolved in TRIZOL (GIBCO) and total RNA was isolated according to the instructions of the manufacturer. Individual RNA samples were divided into two equal portions for measurement of GH mRNA and 18S RNA respectively. After blotting onto a positively charged nylon membrane using a Bio-Dot SF microfiltration unit (Bio-Rad, Hercules, CA, USA), GH mRNA levels in these RNA samples were quantified as described previously (Zhou et al. 2004) by hybridization with a digoxigenin (DIG)-labelled cDNA probe covering the region from 75 to 444 of the grass carp GH cDNA (GenBank no: M27094). In these experiments, parallel probing of a duplicated membrane using a DIG-labelled probe for grass carp 18S RNA was used as an internal control.

\section{Measurement of cAMP production}

Freshly dispersed grass carp pituitary cells were resuspended in carp MEM and evenly seeded at a density of $\sim 8 \times 10^{6}$ cells $/ 2 \mathrm{ml} /$ dish $\left(\sim 0.83 \times 10^{6}\right.$ cells $/ 100 \mathrm{~mm}^{2}$ ) onto poly-D-lysine coated $35 \mathrm{~mm}$ petri dishes. Cell attachment (>90\%) was completed after $3 \mathrm{~h}$ incubation at $28{ }^{\circ} \mathrm{C}$ under $5 \% \mathrm{CO}_{2}$. After that, FBS $(5 \%)$ was introduced and pituitary cells were incubated overnight to allow for the recovery of membrane receptors. On the following day, culture medium was replaced with $0.9 \mathrm{ml}$ HHBSA medium (Yunker et al. 2000) with IBMX $(0 \cdot 1 \mathrm{mM})$. IBMX, the inhibitor for phosphodiesterase, was added to prevent cAMP degradation in pituitary cell cultures. After incubation at $28^{\circ} \mathrm{C}$ for $15 \mathrm{~min}$, hGG treatment was initiated by adding $0.1 \mathrm{ml} 10 \times$ stock solutions at appropriate concentrations. Pituitary cells were then incubated for another $20 \mathrm{~min}$, culture medium was harvested for the measurement of cAMP release and cellular cAMP was extracted by adding $1 \mathrm{ml}$ ice-cold absolute ethanol. These cAMP samples were freeze-dried and stored at $-40{ }^{\circ} \mathrm{C}$ until their cAMP contents were assayed by a Biotrak $\left[{ }^{125}\right]$ cAMP RIA kit (Amersham). In these experiments, cAMP production was defined as the sum of cellular cAMP content and cAMP released into the culture medium.

\section{Immunohistochemical staining of grass carp pituitary cells}

Pituitaries were freshly excised from grass carps, fixed in Bouin's fixative at $4{ }^{\circ} \mathrm{C}$, and embedded in paraffin wax according to standard procedures. Pituitary sections of $5 \mu \mathrm{m}$ in thickness were prepared and mounted onto slides precoated with 2\% 3-aminopropyltriethoxy silane (Sigma). Immunohistochemical staining was performed using a Vectastain ABC kit (Vector Laboratories, Burlingame, CA, USA) according to the manufacturer's instructions. Antisera for carp LH (or GTH-II) and prolactin (PRL) were used at 1:1000 dilution, which matched the doses of LH antiserum used in immunoneutralization. These antisera were a generous gift from Dr R E Peter (University of Alberta, Canada) and have previously been confirmed to be specific for carp LH and PRL respectively (Wong et al. 1998a). The LH antiserum used in immunostaining and immunoneutralization has no cross-reactivity with other pituitary hormones (Ge \& Peter 1994).

\section{Western blot for $\mathrm{GH}$ release and $\mathrm{GH}$ content}

Western blot was conducted to study the effects of LH immunoneutralization on basal GH release and GH content in grass carp pituitary cells. Pituitary cells were seeded in 6-well plates at a density of $\sim 12 \times 10^{6}$ 
cells $/ 3 \mathrm{ml} /$ well $\left(\sim 1.25 \times 10^{6}\right.$ cells $\left./ 100 \mathrm{~mm}^{2}\right)$ and incubated with increasing levels of $\mathrm{LH}$ antiserum for $48 \mathrm{~h}$ or exposed to LH antiserum (1:2500) for $2 \mathrm{~h}, 24 \mathrm{~h}$ and $48 \mathrm{~h}$ respectively. After immunoneutralization, culture medium was harvested for monitoring of $\mathrm{GH}$ secretion. Pituitary cells were lysed in distilled water by three cycles of freezing and thawing and the lysate obtained was cleared by centrifugation to remove cell debris. These protein samples were then size fractionated by SDS-PAGE in duplicate under denaturing conditions. One of the gels was stained with Coomassie blue to visualize protein bands whereas the other one was transblotted onto an Immobilon-P membrane (Millipore, Beford, MA, USA) by low-current electrotransfer for $2 \mathrm{~h}$ at $50 \mathrm{~V}$. After overnight blocking with $2 \%$ nonfat dried milk, the membrane was incubated with $\mathrm{GH}$ antiserum at 1:40 000 dilution for $1.5 \mathrm{~h}$. The antiserum used for Western blot was previously validated to be specific for grass carp GH without cross-reactivity with GTH and PRL (Wong et al. 1998a). Following incubation, the membrane was washed four times to remove the unbound primary antiserum and horseradish peroxidase-conjugated goat anti-rabbit IgG (Bio-Rad) was added for signal development. Chemiluminescence signal was detected using Super-Signal West Pico (PIERCE, Rockford, IL, USA) as the substrate and quantified using an IC440 CF Kodak digital image station (Eastman Kodak). Since the antisera for LH and GH were raised in the rabbit, two 'positive' bands could be detected in the Western blot for GH release, namely a $33 \mathrm{kDa}$ band for LH antiserum (used in immunoneutralization) and a $22 \mathrm{kDa}$ band for GH immunoreactivity detected by GH antiserum. To differentiate the two bands, a blank control with culture medium containing LH antiserum without incubation with pituitary cells was included. In this case, only the $33 \mathrm{kDa}$ band for $\mathrm{LH}$ antiserum was detected.

\section{RT-PCR of LH receptor in laser capture microdissection (LCM)-isolated somatotrophs}

Cytospin preparation of grass carp pituitary cells $(\sim 5 \times$ $10^{4}$ cells/slide) was prepared and subjected to immunostaining with GH antiserum (1:8000). After staining, pituitary cells were dehydrated in ethanol, cleared in xylene, and air-dried prior to laser capture microdissection (LCM). Immuno-identified somatotrophs were isolated with Capsure HS LCM Caps using a PixCell II LCM system (Arcturus Engineering Inc., Mountain View, CA, USA) with infra red (IR) laser setting at $65 \mathrm{~mW}$, pulse duration at $0 \cdot 8-1 \cdot 2 \mathrm{~ms}$, and beam size at $7.5 \mu \mathrm{m}$ in diameter. For single cell PCR, only one somatotroph was captured on individual LCM Caps and total RNA was extracted using TRIZOL. After DNase I digestion and reverse transcription, PCR was conducted using primers covering the cDNA sequence between
TMD II and III of the grass carp LH receptor (LHR), and the authenticity of PCR product $(213 \mathrm{bp}$ ) was confirmed by Southern blot (data not shown). In these experiments, RT-PCR of $\beta$-actin was used as an internal control.

\section{Real-time PCR measurement of mature GH mRNA and GH primary transcripts}

To examine the effects of LH immunoneutralization on the expression of mature GH mRNA and GH primary transcripts, pituitary cells were cultured in 12-well clustered plates (Costar) at a seeding density of $\sim 5 \times$ $10^{6}$ cells $/ 2 \mathrm{ml} /$ well $\left(\sim 1 \cdot 25 \times 10^{6}\right.$ cells $\left./ 100 \mathrm{~mm}^{2}\right)$. After treatment with increasing levels of LH antiserum, pituitary cells were dissolved in TRIZOL and the total RNA isolated was treated with DNase I to remove genomic DNA contamination. After that, reverse transcription (RT) was performed with Superscript II (GIBCO) and the RT samples were then subjected to quantitative PCR for mature GH mRNA and GH primary transcripts (Zhou et al. 2004) using a RotorGene 2000 Real-Time PCR System (Corbett Research, Eight Mile Plains, NSW, Australia). The specificity of PGR reactions was confirmed by melting analysis (melting temperature $=92.2^{\circ} \mathrm{C}$ for mature $\mathrm{GH}$ mRNA and $91.4{ }^{\circ} \mathrm{C}$ for $\mathrm{GH}$ primary transcript) and ethidium bromide staining of PCR products in 2\% agarose gels.

\section{Measurement of grass carp GH promoter activity}

A 986 bp 5' promoter of grass carp GH gene was subcloned into pGL3.Basic (Promega) to give pGH $(-986)$.Luc for transfection studies in $\alpha \mathrm{T} 3-1$ and GH4C1 cells. $\alpha \mathrm{T} 3-1$ cells were maintained in monolayer culture in high glucose DMEM with $10 \%$ FBS at a seeding density of $\sim 5 \times 10^{5}$ cells $/ 0.2 \mathrm{ml} /$ well in a 96-well clustered plate the day before transfection. GH4C1 cells were cultured in a similar manner except that Ham F-10 with $10 \%$ FBS was used as the culture medium and the seeding density was reduced to $\sim 5 \times$ $10^{4}$ cells $/ 0 \cdot 2 \mathrm{ml} /$ well. After overnight incubation, the cells were washed in OPTIMEM (GIBCO). Transfection medium was prepared by mixing $0.3 \mu \mathrm{l}$ lipofectamine with $0 \cdot 1 \mu \mathrm{g}$ plasmid DNA in $100 \mu \mathrm{l}$ OPTIMEM. After incubation for $30 \mathrm{~min}$, the transfection medium was carefully overlaid onto the cells in individual wells. Since $\alpha$ T3 -1 cells are a GTH cell line with endogenous expression of LH receptors but do not express Pit-1 to support GH promoter activity, co-transfection with the carp Pit-1-expressing vector pcDNA.gcPit- 1 was performed. In the case of GH4C1 cells, a rat GH cell line with endogenous Pit-1 but no expression of LH receptors, co-transfection with the salmon LH receptor-expressing vector pSG5.LHR was conducted. In these studies, plasmid DNA used 
for transfection $(0 \cdot 1 \mu \mathrm{g} /$ well $)$ was composed of pGH( - 986).Luc, pcDNA.gcPit-1 (for $\alpha \mathrm{T} 3-1$ cells) or pSG5.LHR (for GH4C1 cells) and pEGFP-N1 (Clontech) at a ratio of $8: 1: 1$. The green fluorescence protein (GFP)-expressing pEGFP-Nl was used as an internal control to monitor transfection efficiency and to normalize the data of luciferase expression. After transfection for $6 \mathrm{~h}$, transfection medium was replaced with normal culture medium and the transfected cells were allowed to recover for $16 \mathrm{~h}$ before the initiation of hCG treatment. The duration of drug treatment was routinely fixed at $24 \mathrm{~h}$. After drug treatment, transfected cells were dissolved in $100 \mu \mathrm{l}$ Reporter Lysis Buffer (Promega). Luciferase activity in $25 \mu \mathrm{l}$ lysate was assayed in a Lumat LB9507 luminometer (EG \& G, Gaitherburg, MD, USA) with a $2 \mathrm{~s}$ delay and $10 \mathrm{~s}$ integration in $100 \mu \mathrm{l}$ Luciferase Assay Reagent (Promega). GFP expression in $50 \mu$ lysate was detected by fluorescence measurement using a CytoFluor 4000 Multi-Well Plate Reader (Perspective Biosystem, Framingham, MA, USA).

\section{Data transformation and statistics}

GH mRNA levels were quantified in terms of 'arbitrary light unit' and normalized against 18S RNA of the same sample. In this study, no significant differences were observed in terms of $18 \mathrm{~S}$ RNA expression and these normalized data were simply transformed into "\% Control' for statistical analysis. In the case of real-time PCR, standard curves with a dynamic range $\geq 10^{5}$ and a correlation coefficient $\left(r^{2}\right) \geq 0.95$ were used for data calibration. Levels of mature GH mRNA and GH primary transcript were expressed as 'femtomole/million cells' and 'attomole/million cells' respectively. The half-life ( $\left.\mathrm{T}^{\frac{1}{2}}\right)$ of GH transcripts was deduced based on the one phase exponential decay model using GraphPad Prism 3.02 software (GraphPad, San Diego, CA, USA). Luciferase activity was normalized against GFP expression in the same sample. Given that GFP levels were relatively stable in this study, these normalized data were also transformed into '\%Control' to facilitate the pooling of data from separate experiments. Data presented were analysed using ANOVA followed by Fisher's least significance difference (LSD) test. Differences were considered significant at $P<0 \cdot 05$.

\section{Results}

\section{Effects of LH on 'steady-state' GH mRNA expression}

To test if LH can modify GH synthesis directly at the pituitary level, a static incubation approach was used to examine the effects of hCG on 'steady-state' GH mRNA expression in primary cultures of grass carp pituitary cells. hCG is a placental GTH and has been used as a pharmacological tool to probe the biological actions mediated by LH receptors, mainly for its long half-life, higher affinity for receptors, and commercial availability (Ascoli et al. 2002). Recently, a lack of cross-reactivity of hCG with FSH receptors in fish has been reported (Laan et al. 2002), confirming that hGG can be used as a functional homologue of LH in teleosts. In this study, a 48-h incubation of pituitary cells with increasing concentrations of hCG $(10-50 \mathrm{IU} / \mathrm{ml})$ resulted in a dose-dependent increase in 'steady-state' GH mRNA levels (Fig. 1A). The minimal dose of hCG tested to trigger a rise in GH mRNA expression was noted at 20 $\mathrm{IU} / \mathrm{ml}$. The stimulatory effects of hCG reached a plateau phase at doses higher than $40 \mathrm{IU} / \mathrm{ml}$ (data not shown). To study the functional role of endogenous $\mathrm{LH}$ in regulating $\mathrm{GH}$ synthesis, immunoneutralization was performed using an antiserum raised against carp LH. Removal of endogenous LH released into the culture medium by applying increasing levels of $\mathrm{LH}$ antiserum inhibited basal expression of GH mRNA in a dose-related fashion (Fig. 1B). A significant drop in GH mRNA levels was noted at 1:10000 dilution of LH antiserum. When applied at 1:2500 dilution, LH antiserum totally abolished GH mRNA expression in grass carp pituitary cells. In parallel experiments, LH immunoneutralization was not effective in altering basal expression of thyrotrophin (TSH) $\beta$ and FSH $\beta$ mRNA (data not shown). Apparently, the inhibitory effect on GH mRNA expression was specific to LH antiserum as normal rabbit serum (NRS) or an antiserum raised against carp PRL did not alter GH mRNA levels when applied at 1:1000 dilution (Fig. 2A). The specificity of these antisera was further confirmed by immunostaining of grass carp pituitary sections using 1:1000 dilution of LH and PRL antisera. In this case, PRL immunoreactivity was identified in lactotrophs located in the RPD. In a consecutive section, LH immunoreactivity exhibited a patchy distribution in the PPD but not in RPD or NIL (Fig. 2B). This distribution pattern of LH immunoreactivity is consistent with that reported previously for gonadotrophs in the grass carp pituitary (Wong et al. $1998 a)$.

\section{LH immunoneutralization on GH release and GH content}

To test if $\mathrm{LH}$ also regulates $\mathrm{GH}$ secretion at the pituitary level, grass carp pituitary cells were treated for $48 \mathrm{~h}$ with increasing doses of LH antiserum $(1: 10000$ to $1: 1000)$. GH released into the culture medium was analysed by Western blot using an antiserum specific for grass carp GH (Fig. 3A). In our assay system, the second antibody for signal development was raised against rabbit $\operatorname{IgG}$ and could recognize both the protein bands for $\mathrm{LH}$ antiserum $(33 \mathrm{kDa})$ and $\mathrm{GH}$ immunoreactivity $(22 \mathrm{kDa})$. In this case, treatment with increasing levels of LH 


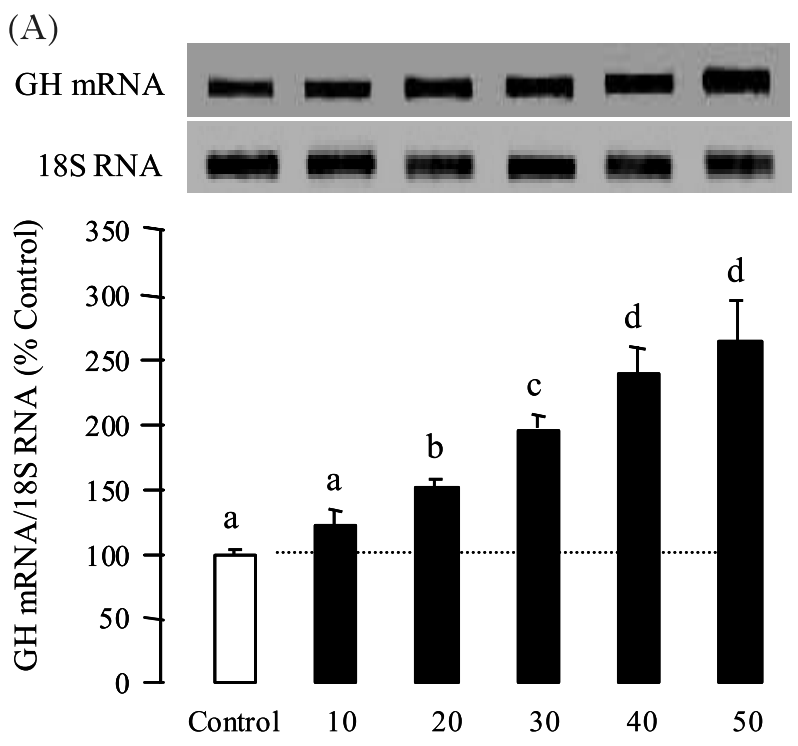

HCG concentration (IU/ml)

(B)
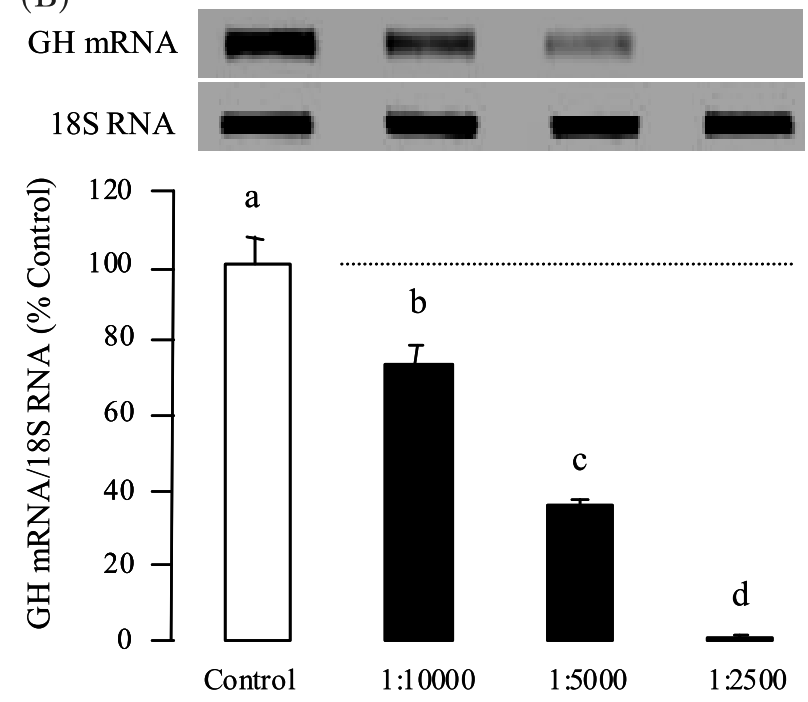

Dilution of LH antiserum

Figure 1 Effects of hCG and LH immunoneutralization on $\mathrm{GH}$ mRNA expression in grass carp pituitary cells. Pituitary cells were exposed to increasing doses of hCG $(\mathrm{A}, 10-50 \mathrm{IU} / \mathrm{ml})$ and $\mathrm{LH}$ antiserum (B, 1:10 000-1:2500) for $48 \mathrm{~h}$ under static incubation. After that, total RNA samples were extracted for quantitation of steady-state GH mRNA levels. Parallel measurement of $18 \mathrm{~S}$ rRNA was conducted to serve as an internal control. Data presented (means \pm S.E.M., $n=8$ ) are pooled results from eight separate experiments (each with triplicate treatments). Treatment groups denoted by different letters represent a significant difference at $P<0.05$ (ANOVA followed by Fisher's LSD test). Representative results of slot blot are also presented for these studies. antiserum resulted in a dose-dependent increase in the $33 \mathrm{kDa}$ antiserum band but a corresponding decrease in the $22 \mathrm{kDa} \mathrm{GH}$ band, suggesting that removal of endogenous LH inhibited basal GH secretion in pituitary cell cultures. Parallel analysis of protein samples prepared from pituitary cells in the same experiment also revealed that the $22 \mathrm{kDa} \mathrm{GH}$ band was increased after LH immunoneutralization. The inhibitory action of $\mathrm{LH}$ antiserum on $\mathrm{GH}$ release was also found to be time-dependent (Fig. 3B). When compared with the time-matched control, a drop in the $22 \mathrm{kDa}$ $\mathrm{GH}$ band was noted in the culture medium collected after a 2-h incubation with LH antiserum (1:2500). Although a time-dependent increase in $22 \mathrm{kDa}$ GH band was noted in the control from $2 \mathrm{~h}$ to $48 \mathrm{~h}$, GH immunoreactivity remained at a low level in the groups treated with $\mathrm{LH}$ antiserum. In these experiments, equal loading of protein sample per lane and molecular weight estimation of target bands in the SDS-PAGE gel were confirmed by Coomassie blue staining. A blank control was also included with 'cell-free' culture in MEM containing 1:500 dilution of LH antiserum. Given that only a single $33 \mathrm{kDa}$ band was noted in the blank control which was clearly separated from the $22 \mathrm{kDa}$ $\mathrm{GH}$ band in the experimental control (without LH antiserum treatment), the possibility of cross-reactivity of $\mathrm{GH}$ antiserum with LH antiserum is highly unlikely.

\section{Expression of LH receptors in carp somatotrophs}

To test if somatotrophs were the target cells for hCG treatment at the pituitary level, RT-PCR of LH receptors was performed in LCM isolated immunoidentified carp somatotrophs (Fig. 4A). In this study, only a single somatotroph was captured on individual Capsure HS LCM Caps and potential contamination by other pituitary cell types could be avoided. Using primers specific for grass carp LH receptor, a $213 \mathrm{bp}$ PCR product was detected in the RT samples of isolated somatotrophs (i.e. GH cells \#.1 and \#.2) and mixed populations of carp pituitary cells (Fig. 4B). The $213 \mathrm{bp}$ PCR product for LH receptor was also detected in the gonad, which was used as a positive control for these experiments. Parallel PCR of the RT samples prepared from somatotrophs with primers for TSH $\beta$ and FSH $\beta$ mRNA, however, could not yield any detectable PCR products, confirming the absence of contamination by other pituitary cell types during the LCM procedures (data not shown).

\section{Interactions of $\mathrm{LH}$ and GH-releasing factors on $\mathrm{GH}$ mRNA expression}

To study the functional relevance of $\mathrm{LH}$ in regulating GH synthesis in grass carp, in vitro interactions of LH with the GH-releasing factors in fish, including PACAP, 
$\mathrm{GnRH}$, and dopamine, were examined. In this case, a 48-h treatment of pituitary cells with hCG $(30 \mathrm{IU} / \mathrm{ml})$, PACAP $(1 \mu \mathrm{M})$, GnRH $(1 \mu \mathrm{M})$ and the dopamine agonist, APO $(1 \mu \mathrm{M})$ consistently increased basal levels of 'steady-state' GH mRNA (Fig. 5A-G). When hCG (30 $\mathrm{IU} / \mathrm{ml})$ was given together with PACAP $(1 \mu \mathrm{M}$, Fig. $5 \mathrm{~A})$ or APO $(1 \mu \mathrm{M}$, Fig. $5 \mathrm{~B})$, the stimulatory effect of hCG on GH mRNA levels was enhanced in an additive manner. A similar additive effect, however, was not observed with simultaneous treatment of hCG (30 $\mathrm{IU} / \mathrm{ml})$ and $\mathrm{GnRH}(1 \mu \mathrm{M}$, Fig. $5 \mathrm{C})$. To confirm the role of LH on the stimulatory effects of these GH-releasing factors, LH immunoneutralization was performed to test the responsiveness of pituitary cells to these stimulators in the absence of endogenous LH. Increasing concen-

(A)
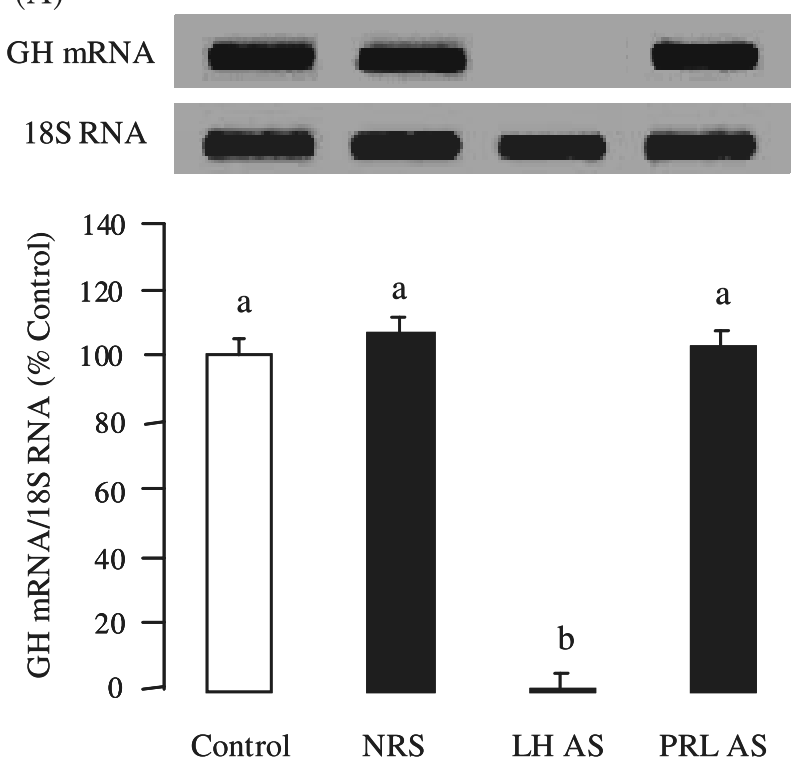

(B)

LH AS (1:1000)
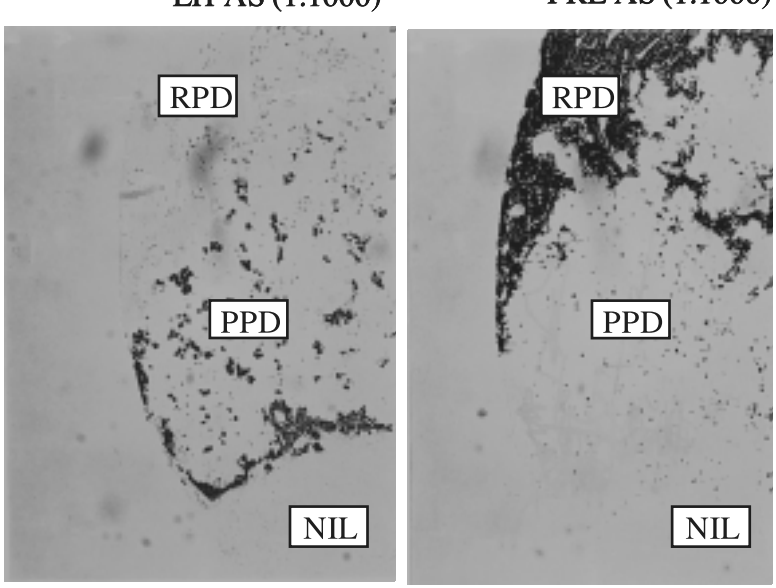

trations of LH antiserum (1:10000 to 1:2500) dosedependently reduced basal GH mRNA levels as well as the stimulatory effects of PACAP $(1 \mu \mathrm{M}$, Fig. $6 \mathrm{~A})$, APO $(1 \mu \mathrm{M}$, Fig. $6 \mathrm{~B})$ and GnRH $(1 \mu \mathrm{M}$, Fig. $6 \mathrm{C})$ on $\mathrm{GH}$ mRNA expression. The stimulatory actions of PACAP and GnRH were abrogated by LH antiserum at 1:10 000 dilution, whereas a higher level of $\mathrm{LH}$ antiserum (1:5000) was required to block APO-induced GH mRNA expression. Under a high dose of LH antiserum (1:2500), GH mRNA expression was almost undetectable even in the presence of GH-releasing factors.

\section{Molecular mechanisms for $\mathrm{LH}$ regulation of GH gene expression}

'Steady-state' GH mRNA, a dynamic balance between GH mRNA production and degradation, was assayed in the preceding experiments to serve as an index for $\mathrm{GH}$ synthesis. As a logical extension of our study, we also examined the role of transcript stability and gene transcription in LH-induced GH mRNA expression in grass carp pituitary cells. To test if $\mathrm{LH}$ can modify the half-life $\left(T_{1 / 2}\right)$ of $\mathrm{GH}$ transcripts, the clearance curves of GH mRNA were constructed after exposing pituitary cells to the transcription inhibitor, actinomycin D $(8 \mu \mathrm{M})$ in the presence of hCG $(40 \mathrm{IU} / \mathrm{ml})$ or $\mathrm{LH}$ antiserum (1:5000). When compared with the control, hCG treatment had no effect on GH mRNA clearance and did not alter the $\mathrm{T}_{1 / 2}$ value of $\mathrm{GH}$ transcripts $(19 \mathrm{~h}$, 95\% confidence interval: $17 \cdot 7 \mathrm{~h}-22 \cdot 3 \mathrm{~h}$; Fig. $7 \mathrm{~A}$ ). In contrast, the GH mRNA clearance curve was shifted to the right by treatment with LH antiserum (Fig. 7B) with an increase in $\mathrm{T}_{1 / 2}$ value from $12 \mathrm{~h}(95 \%$ confidence interval: $9 \cdot 7 \mathrm{~h}-14 \cdot 2 \mathrm{~h})$ to $35 \mathrm{~h}(95 \%$ confidence interval: $32.5 \mathrm{~h}-39 \cdot 9 \mathrm{~h})$. These results indicate that GH transcript stability was enhanced after removal of endogenous LH by immunoneutralization.

To further examine the role of $\mathrm{LH}$ on $\mathrm{GH}$ gene transcription in grass carp pituitary cells, quantitative

Figure 2 Selectivity of LH antiserum for immunoneutralization. (A) Effects of LH antiserum, PRL antiserum, and normal rabbit serum on GH mRNA expression. Pituitary cells were incubated for $48 \mathrm{~h}$ with LH antiserum (LH AS; 1:1000), PRL antiserum (PRL AS; 1:1000), and normal rabbit serum (NRS; 1:1000). Data presented (means \pm S.E.M., $n=8$ ) are pooled results from eight experiments (each with triplicate treatments). Treatment groups labelled with different letters represent a significant difference at $P<0.05$ (ANOVA followed by Fisher's LSD test). (B) Immunohistochemical staining of gonadotrophs and lactotrophs in grass carp pituitary sections. Pituitary sections were stained with a Vectastain $A B C$ kit using the antisera for carp LH (1:1000) and PRL (1:1000) respectively. LH immunoreactivity was noted exclusively in the proximal pars distalis (PPD), whereas PRL immunoreactivity was restricted to the rostral pars distalis (RPD). Immunoreactivity of LH or PRL could not be detected in the neurointermediate lobe (NIL). 
(A)

Dose dependence of GH release and GH content after adding LH antiserum

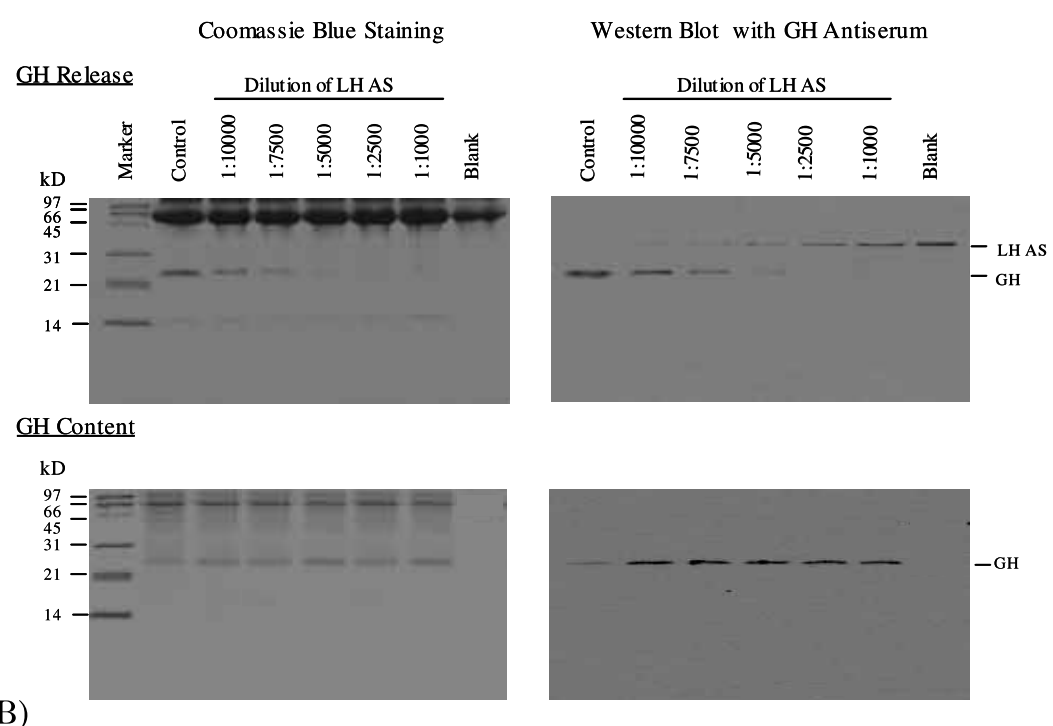

(B)

Time Course of $\mathrm{GH}$ release after adding $\mathrm{LH}$ antiserum

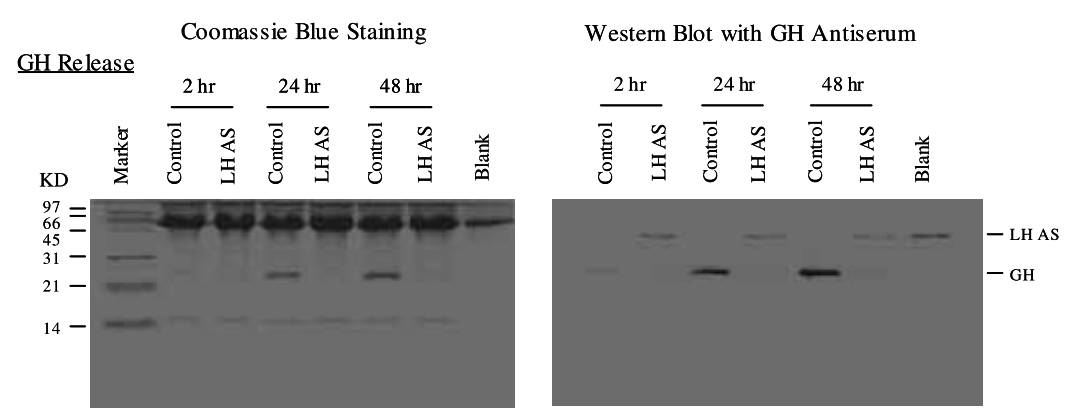

Figure 3 Effects of LH immunoneutralization on basal GH release and cellular GH content in grass carp pituitary cells. (A) Dose dependence of LH antiserum treatment on GH release and GH content. Pituitary cells were exposed to increasing levels of LH antiserum (LH AS; 1:1000 to 1:10 000) for $48 \mathrm{~h}$ under static incubation. Culture medium was harvested for quantitation of basal GH release. Pituitary cells were lysed in distilled water and the protein extracts prepared were used for the measurement of cellular GH content. (B) Time course of LH immunoneutralization on GH secretion. Pituitary cells were incubated with LH antiserum $(1: 2500)$ for $2 \mathrm{~h}, 24 \mathrm{~h}$ and $48 \mathrm{~h}$ respectively, and culture medium was harvested to monitor changes in GH secretion. $\mathrm{GH}$ levels in culture medium or in protein extracts prepared from grass carp pituitary cells were analysed using Western blot. Coomassie blue staining of the protein gels is presented in the right panels and the corresponding Western blots for GH immunoreactivity $(22 \mathrm{kDa})$ are presented in the left panels. Besides the control without antiserum treatment, a blank control with culture medium containing LH antiserum but no incubation with pituitary cells was also included to identify the immunoreactivity caused by $\mathrm{LH}$ antiserum ( $33 \mathrm{kDa})$. The experiments were repeated three times with similar results and only representative gel pictures are presented.

analysis of GH primary transcripts by real-time PCR was performed after a 48-h incubation with increasing levels of LH antiserum (1:10 000 to 1:1000). As a parallel control, mature GH mRNA levels were also measured in the same experiment. Calibration of data for mature GH mRNA (Fig. 8A) and GH primary transcripts (Fig.
8B) was conducted using linear regression of critical threshold (or CT) values of the standard curve. In this study, immunoneutralization with LH antiserum inhibited basal expression of mature GH mRNA (Fig. 8C) and GH primary transcripts (Fig. 8D) in a dosedependent manner. A significant reduction of mature 
(A)
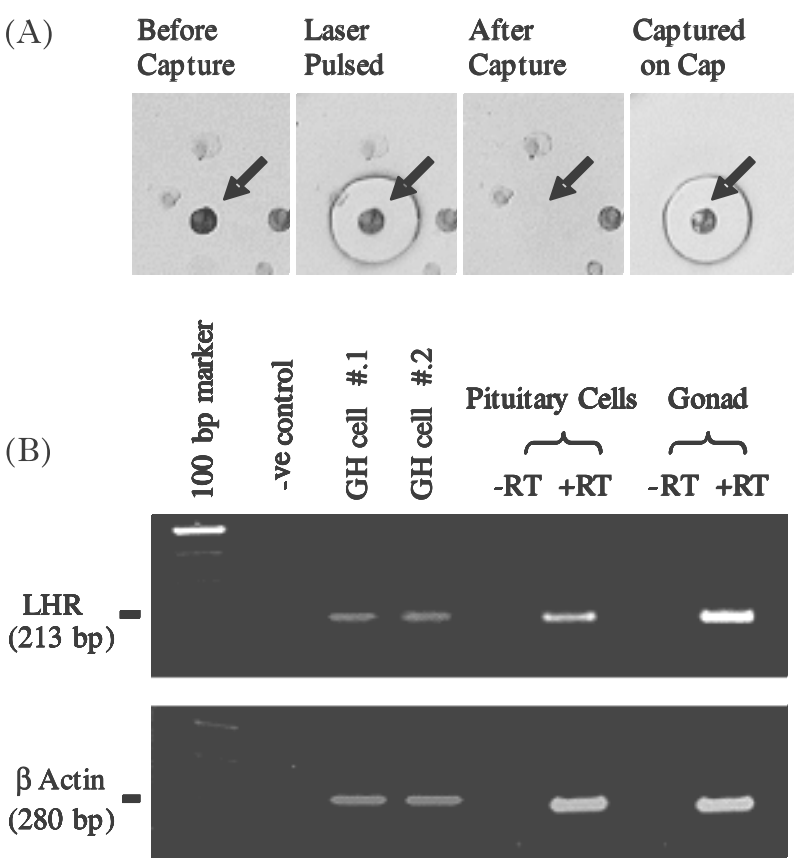

Figure 4 Expression of LH receptors in LCM-isolated somatotrophs. (A) Isolation of single immuno-identified somatotroph from mixed populations of grass carp pituitary cells by laser capture microdissection (LCM). Somatotrophs were immunostained with $\mathrm{GH}$ antiserum $(1: 2500)$ using a Vectastain ABC kit and laser-captured using Capsure HS LCM cap. (B) RT-PCR of LH receptor (LHR) transcripts in LCM-isolated grass carp somatotrophs. Total RNA was prepared from individual somatrophs or mixed populations of carp pituitary cells and reverse transcription was performed in the presence $(+\mathrm{RT})$ or absence (-RT) of Superscript II. RT-PCR of LHR transcripts in the gonad was used as a positive control and PCR of $\beta$-actin was used as the internal control. PCR with distilled water substituted for RT samples was used as a negative control. GH cells \#.1 and \#.2 are representatives of somatotrophs captured for the present study. Since the total RNA isolated from a single cell was very minute, the -RT control was not performed in these samples.

GH mRNA levels was noted at a 1:10 000 dilution of LH antiserum, whereas a higher concentration of antiserum (1:7500) was required to induce a drop in $\mathrm{GH}$ primary transcripts. In these studies, PCR specificity was confirmed by melting analysis and ethidium bromide staining of PCR products (upper panels, Fig. 8C-D). A single $252 \mathrm{bp}\left(\mathrm{T}_{\mathrm{m}}=92.2{ }^{\circ} \mathrm{C}\right)$ and $210 \mathrm{bp}$ PCR products $\left(\mathrm{T}_{\mathrm{m}}=91.4{ }^{\circ} \mathrm{C}\right)$ were consistently observed in samples exposed to increasing levels of LH antiserum after real-time PCR of mature GH mRNA and GH primary transcripts respectively.

To provide further evidence that LH induces GH mRNA expression via activation of GH gene transcription, transfection studies were performed in $\alpha \mathrm{T} 3-1$ and GH4C1 cells. After co-transfection with the Pit-1 expression vector pcDNA.gcPit-1, basal expression of luciferase activity in $\alpha \mathrm{T} 3-1$ cells was increased in a dose-dependent manner by increasing levels of hCG (10 - $50 \mathrm{IU} / \mathrm{ml}$, Fig. 9A). In parallel experiments with GH4C1 cells, a similar dose-dependence of hCGinduced luciferase activity was also noted after co-transfection with the salmon LH receptor expression vector pSG5.LHR (Fig. 9B). However, increasing levels of hCG were unable to further elevate basal luciferase activity in the dose-matched controls with cotransfection of the blank vector pSG5 without the LHR insert.

\section{Post-receptor signalling mechanisms for LH-stimulated GH gene expression}

To elucidate the signalling mechanisms for LH-induced GH gene expression in Chinese grass carp, the functional coupling of LH receptors with the cAMPdependent pathway was examined at the pituitary level. In this case, grass carp pituitary cells were treated for 20 min with increasing levels of hCG $(0 \cdot 5-100 \mathrm{IU} / \mathrm{ml})$ and cAMP production was accentuated in a dose-related fashion (Fig. 10A). In parallel experiments, the stimulatory effect of hCG (40 IU/ml) on $\mathrm{GH}$ mRNA expression was tested with simultaneous treatment with the AC inhibitor, MDL12330A $(20 \mu \mathrm{M})$ and the PKA inhibitor, H89 $(20 \mu \mathrm{M})$. hCG was effective in elevating GH mRNA levels but this stimulatory effect could be abolished by treatment with MDL12330A or H89. In the same study, MDL12330A or H89 alone was also effective in reducing basal GH mRNA expression (Fig. 10B).

Given that LH is known to activate MAPK and PI3K cascades in mammals (Ascoli et al. 2002), the possible role of these pathways in LH-stimulated $\mathrm{GH}$ gene expression was also examined. hCG-induced GH mRNA expression in grass carp pituitary cells was tested in the presence of the P42/44 ${ }^{\mathrm{MAPK}}$ inhibitor, PD98059 $(100 \mu \mathrm{M})$, the P38MAPK inhibitor, SB202190 $(20 \mu \mathrm{M})$, and the PI3K inhibitor, wortmannin $(100 \mathrm{nM})$, and parallel treatment with the JAK2 inhibitor, AG490 $(100 \mu \mathrm{M})$ was used as a negative control. SB202190 and AG490 suppressed basal expression of GH mRNA (Fig. 11B) whereas a similar inhibitory effect was not observed with PD98059 and wortmannin (Fig. 11A). In these studies, the inhibitors for P42/44 MAPK, P38 MAPK, PI3K and JAK2 were also effective in blocking the stimulatory action of hCG $(40 \mathrm{IU} / \mathrm{ml})$ on $\mathrm{GH}$ mRNA expression. To clarify if P42/44 MAPK, P38 MAPK, PI3K and JAK2 are operating downstream of the cAMP-dependent pathway after hCG stimulation, the effect of the $\mathrm{AC}$ activator, forskolin $(10 \mu \mathrm{M})$ on $\mathrm{GH}$ mRNA expression was examined in the presence of SB202190 $(20 \mu \mathrm{M})$, PD98059 $(100 \mu \mathrm{M})$, AG490 $(100 \mu \mathrm{M})$ and wortmannin $(100 \mathrm{nM})$ respectively. Similar to hCG, forskolin increased GH mRNA levels in carp pituitary cells and 
(A)

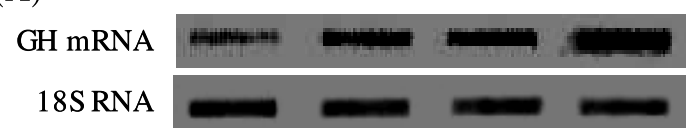

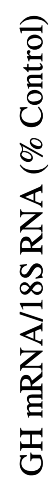

(B)

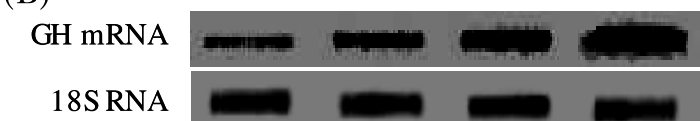

(C)
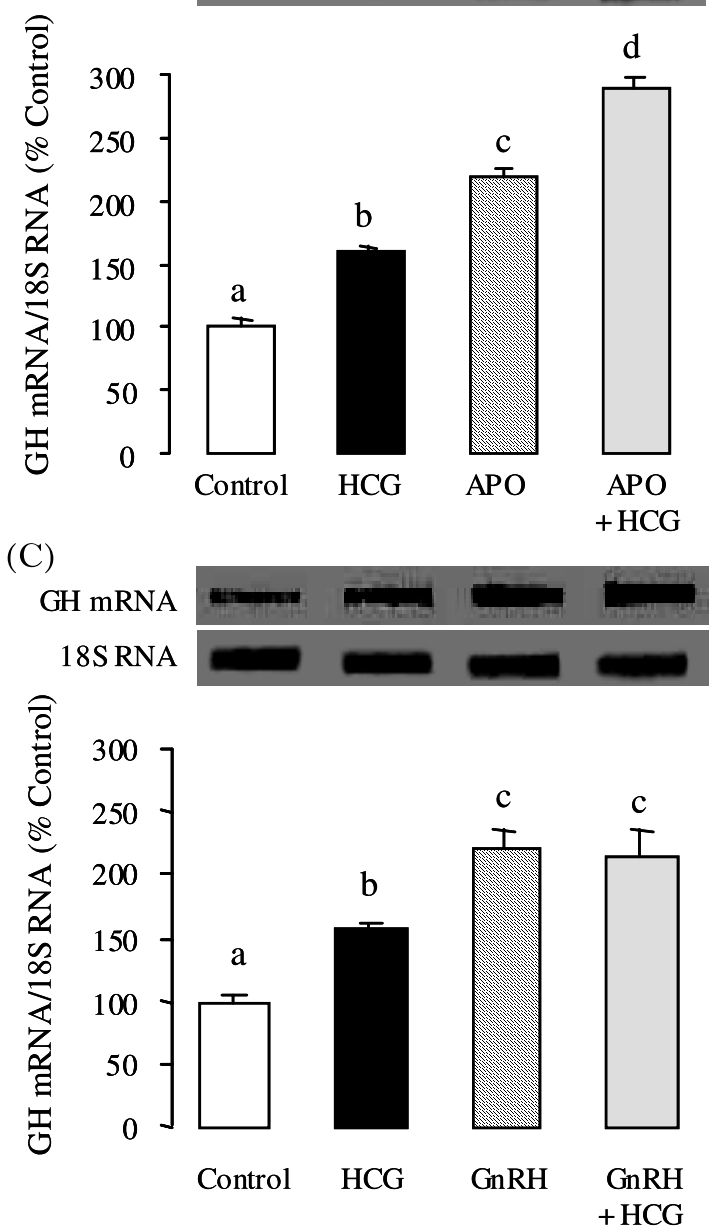

this stimulatory action could be blocked by SB202190 (Fig. 12A), PD98059 (Fig. 12A) and AG490 (Fig. 12B). Forskolin-induced GH mRNA expression, however, was not affected by simultaneous treatment with wortmannin (Fig. 12B).

\section{Discussion}

Gonadotrophins, including $\mathrm{LH}$ and $\mathrm{FSH}$, are well documented to play an essential role in reproductive functions, in particular those related to the processes of gametogenesis and steroidogenesis. The molecular structure of LH receptor has been elucidated (Ascoli et al. 2002) and its functional coupling to steroidogenesis, e.g. in the ovary, is mediated through stimulation of steroidogenic acute regulatory (StAR) protein and cytochrome P450 expression (Wood \& Strauss 2002). Recently, extragonadal expression of LH receptors has been reported, suggesting that LH may have novel functions in 'non-classical' targets (Rao 2001). In the rat, low levels of LH receptor transcripts can be detected in the anterior pituitary (Lei et al. 1993). This finding raises the possibility that LH may play the role of an autocrine/paracrine factor at the pituitary level. In this study, using grass carp pituitary cells as a model, we have demonstrated for the first time that $\mathrm{LH}$ serves as a paracrine factor regulating GH synthesis and secretion in the fish pituitary. In this case, steady-state GH mRNA levels were elevated in a dose-dependent manner by hCG treatment in grass carp pituitary cells. Basal expression of GH mRNA, on the other hand, was suppressed by immunoneutralization using LH antiserum. Besides, treatment with $\mathrm{LH}$ antiserum was also effective in reducing GH secretion in a time- and dose-related fashion. These results, as a whole, provide evidence that endogenous $\mathrm{LH}$ is essential for the maintenance of GH release and GH gene expression in fish pituitary cells. Given that (i) the inhibitory effect of LH antiserum on GH mRNA levels was not mimicked by NRS or PRL antiserum and (ii) LH antiserum at the level used for immunoneutralization could only recognize gonadotrophs but not other pituitary cell types, the inhibitory action of $\mathrm{LH}$ antiserum caused by a cross-reactivity with other pituitary hormones is highly unlikely. Since exogenous LH was effective in increasing

Figure 5 Interactions of hCG with GH-releasing factors in fish on $\mathrm{GH}$ mRNA expression in grass carp pituitary cells. Pituitary cells were incubated for $48 \mathrm{~h}$ with $(\mathrm{A})$ ovine PACAP 38

(PACAP; $1 \mu \mathrm{M}$ ), (B) the dopamine agonist apomorphine (APO; $1 \mu \mathrm{M})$, and $(\mathrm{C})$ salmon $\mathrm{GnRH}(\mathrm{GnRH} ; 1 \mu \mathrm{M})$ in the presence or absence of hCG (30 IU $/ \mathrm{ml})$. Data presented (means \pm S.E.M., $n=8$ ) are pooled results from eight experiments (each with triplicate treatments). Treatment groups denoted by different letters represent a significant difference at $P<0.05$ (ANOVA followed by Fisher's LSD test). 
(A)
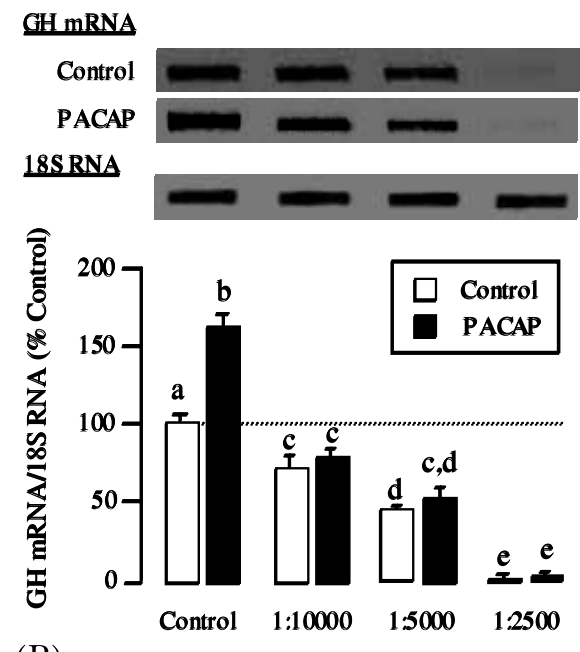

(B)
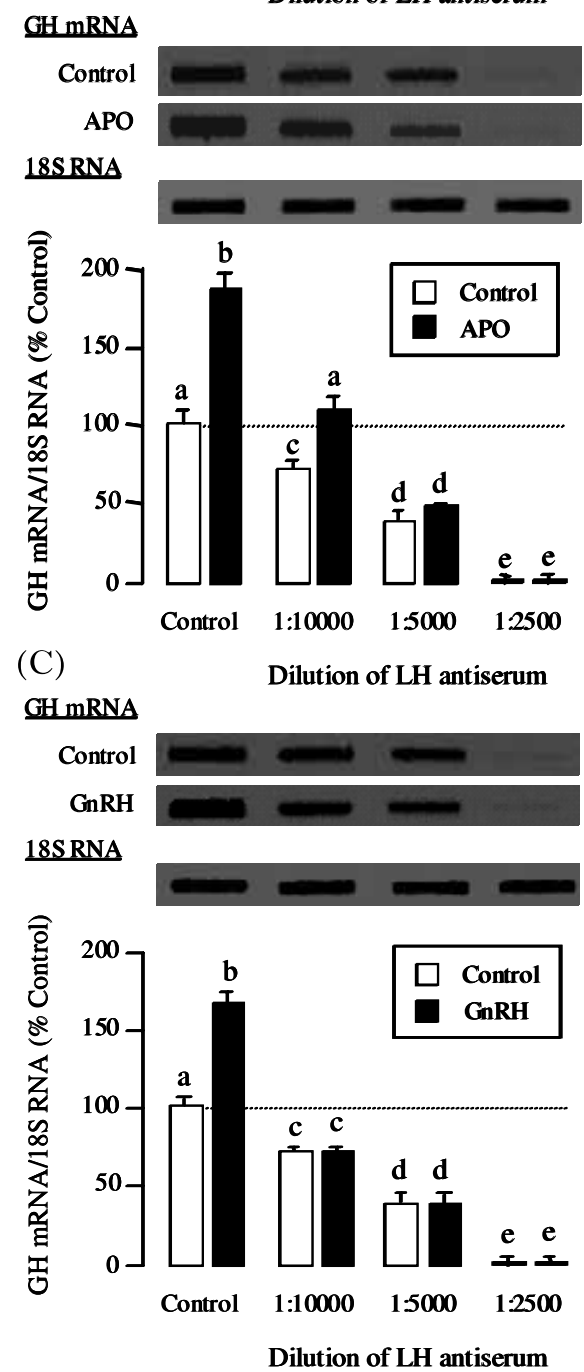

Dilution of LH antiserum
GH mRNA levels, it is conceivable that endogenous LH produced by pituitary cells is not saturating and GH gene expression can be modulated in situ by $\mathrm{LH}$ production at the pituitary level. Using single cell PCR in LCM-isolated carp somatotrophs, the transcripts for LH receptors were also detected, implying that $\mathrm{LH}$ stimulation is acting directly on somatotrophs to modify $\mathrm{GH}$ synthesis and secretion. It is worth mentioning that there was an increase in cellular GH content in carp pituitary cells after LH immunoneutralization. This increase in GH content is suspected to be the result of GH accumulation which occurred during the period of suppressed GH exocytosis. In the rat, a reciprocal relationship between $\mathrm{GH}$ secretion and pituitary GH content has been reported after anterolateral deafferentation of the medial basal hypothalamus (Ieiri et al. 1988). Under static incubation, dopaminergic stimulation is known to inhibit basal GH release but increase GH content in rat pituitary cells (Wood et al. 1987). Apparently, intricate mechanisms operating at the level of transcription and translation may exist in somatotrophs to regulate the dynamic balance among $\mathrm{GH}$ gene expression, cellular GH stores and GH exocytosis.

To examine the physiological implication of the paracrine effects of $\mathrm{LH}$ on $\mathrm{GH}$ gene expression, functional interactions of hGG with documented GH-releasing factors in fish, namely $\mathrm{GnRH}$, dopamine and PACAP, were also tested in carp pituitary cells. In teleosts, GnRH functions as a hypothalamic hormonereleasing factor regulating $\mathrm{LH}$ and $\mathrm{GH}$ release at the pituitary level (Chang et al. 2000). Its stimulatory actions on GH mRNA expression in fish pituitary cells have been reported in tilapia (Melamed et al. 1996) and common carp (Li et al. 2002). Since GnRH receptors have been identified in fish somatotrophs, e.g. in goldfish (Cook et al. 1991), it is commonly accepted that GnRH stimulates GH synthesis and secretion in fish by direct actions on somatotrophs. Similar to GnRH, dopamine also serves as a GH-releasing factor in fish (Wong et al. 1993a) via activation of pituitary D1 receptors (Wong et al. 1993b). In tilapia, dopaminergic stimulation can induce GH mRNA expression at the pituitary cell level (Melamed et al. 1996). PACAP, the latest member of the secretin/glucagon peptide family, has been proposed to be the ancestral GHRH in lower vertebrates (Montero

Figure 6 Effects of LH immunoneutralization on GH mRNA expression induced by $\mathrm{GH}$-releasing factors in grass carp pituitary cells. Pituitary cells were incubated for $48 \mathrm{~h}$ with $(\mathrm{A})$ ovine PACAP 38 (PACAP; $1 \mu \mathrm{M})$, (B) the dopamine agonist apomorphine (APO; $1 \mu \mathrm{M})$, and (C) salmon $\mathrm{GnRH}(\mathrm{GnRH}$; $1 \mu \mathrm{M})$ in the presence or absence of increasing levels of $\mathrm{LH}$ antiserum (1:10 000 to 1:2500). Data presented (means \pm S.E.M., $n=8$ ) are pooled results from eight experiments (each with triplicate treatment). Treatment groups labelled with different letters represent a significant difference at $P<0.05$ (ANOVA followed by Fisher's LSD test). 
(A)
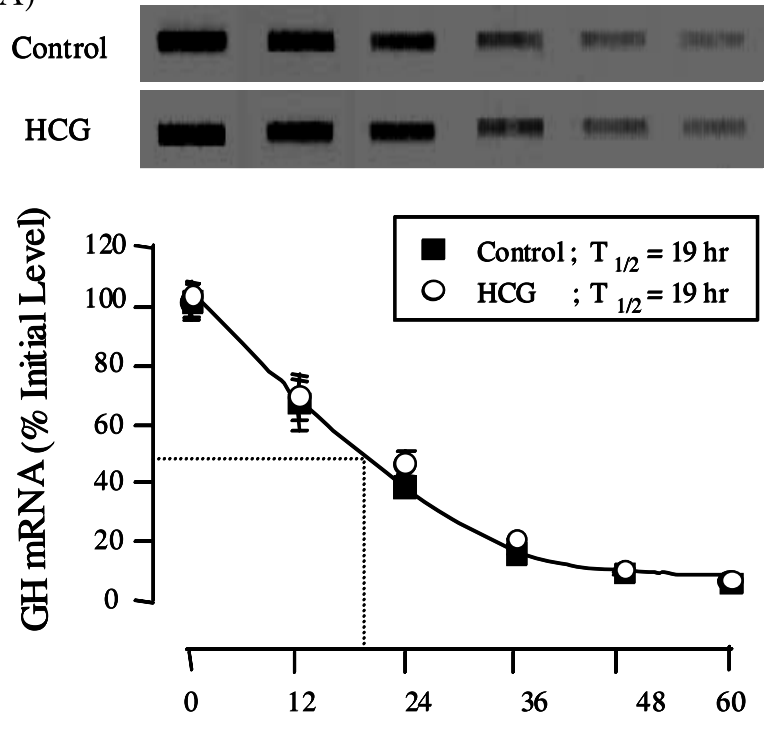

Hours after Actinomycin D treatment

(B)
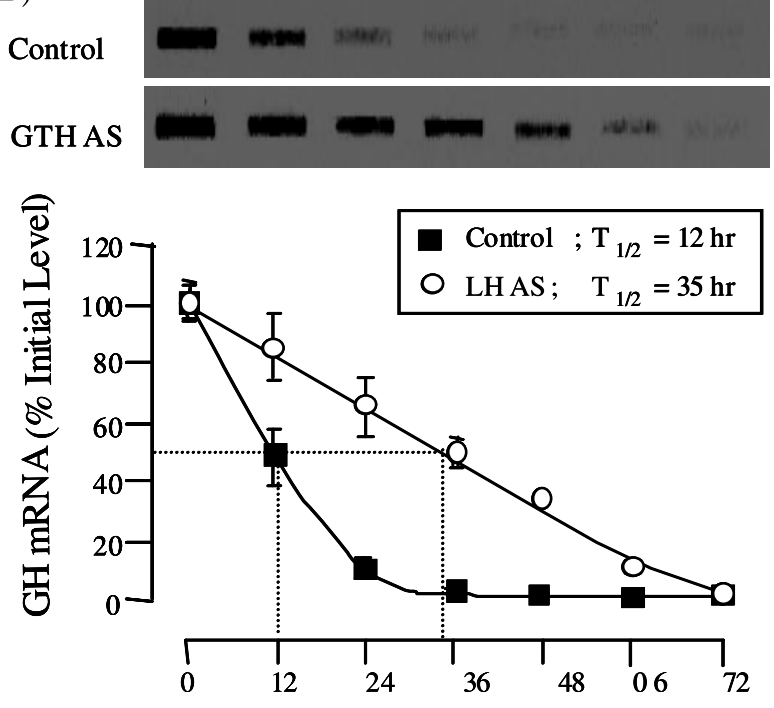

Hours after Actinomycin D treatment

Figure 7 Effects of (A) hCG and (B) LH immunoneutralization on GH mRNA stability in grass carp pituitary cells. Pituitary cells were incubated with actinomycin $D(8 \mu \mathrm{M})$ in the presence or absence of either hCG $(40 \mathrm{IU} / \mathrm{ml})$ or $1: 5000 \mathrm{LH}$ antiserum for the duration as indicated. Total RNA samples were isolated at the respective time points for the construction of $\mathrm{GH}$ mRNA clearance curves. The half-life (T1/2) of $\mathrm{GH}$ transcript is defined as the time required for $\mathrm{GH}$ mRNA levels to drop to $50 \%$ of the original value. The experiments were repeated three times (each with quadruplicate treatments) and only the representative results of a single experiment are presented $(n=4)$. In these studies, the trend of T1/2 responses to drug treatment was similar between separate experiments.
(A)
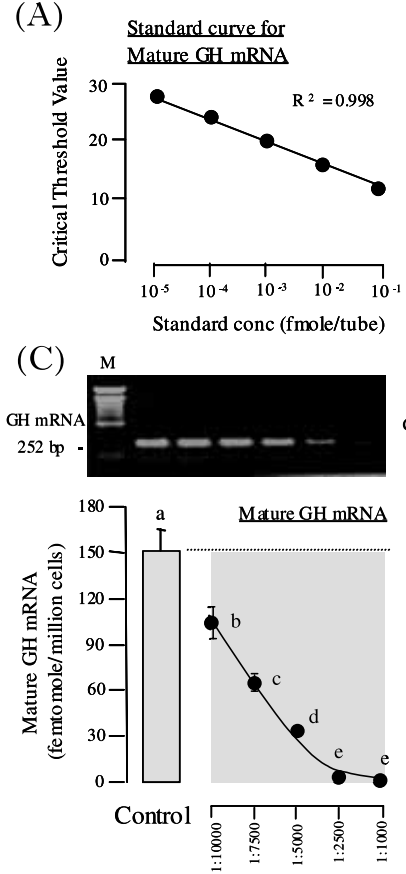

Dilution of LH antiserum

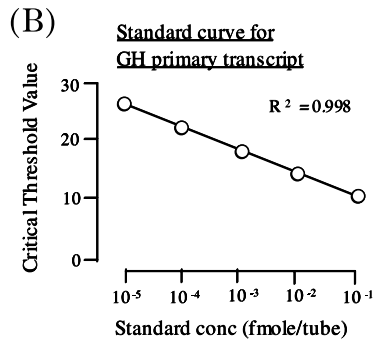

(D) $\mathrm{M}$
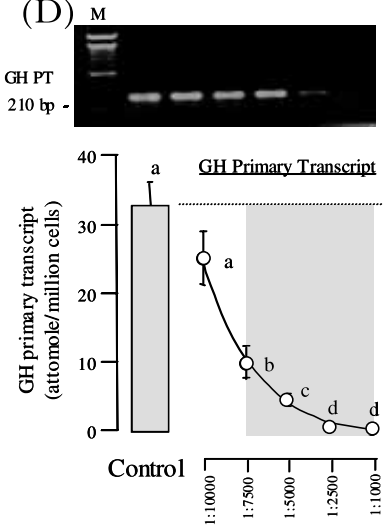

Dilution of LH antiserum
Figure 8 Quantitative real-time PCR for mature GH mRNA and $\mathrm{GH}$ primary transcripts after $\mathrm{LH}$ immunoneutralization. (A and B) Standard curves for mature GH mRNA (A) and GH primary transcript (B). A tenfold serial dilution of the PCR standard (i.e. plasmid containing $\mathrm{GH}$ cDNA or full-length $\mathrm{GH}$ gene) was used to generate the standard curve. The resulting critical threshold (CT) values were plotted as a function of the levels of PCR template. (C and D) Effects of $\mathrm{LH}$ immunoneutralization on the expression levels of mature GH mRNA (C) and GH primary transcripts (PT; D). Pituitary cells were incubated for $48 \mathrm{~h}$ with increasing concentrations of LH antiserum (1:10 $000-1: 1000)$. PCR was conducted using primers specific for exon II and III (for mature GH mRNA) or flanking the junction between exon II and intron II of grass carp GH gene (for GH primary transcript). Data presented (means \pm S.E.M., $n=8$ ) are pooled results from eight experiments (each with triplicate treatments). Treatment groups denoted by different letters represent significant difference at $P<0.05$ (ANOVA followed by Fisher's LSD test). The shaded area represents the doses of $\mathrm{LH}$ antiserum inducing a significant drop of mature GH mRNA or GH primary transcripts. Representative results of ethidium bromide-stained PCR products are also presented for these experiments.

et al. 2000). Its role as a novel GH-releasing factor in fish has been confirmed (Wong et al. 2000) and its GH-releasing effect is mediated by pituitary PAC-I receptors (Wong et al. 1998b). Using RT-PCR coupled to LCM, the transcripts for D1 and PAC-1 receptors have recently been detected in somatotrophs isolated from grass carp and goldfish pituitary cells respectively (W K W Ko and A O L Wong, unpublished results). These results imply that dopamine and PACAP also act directly on somatotrophs for GH regulation. In the present study, basal levels of steady-state GH mRNA in 
(A)

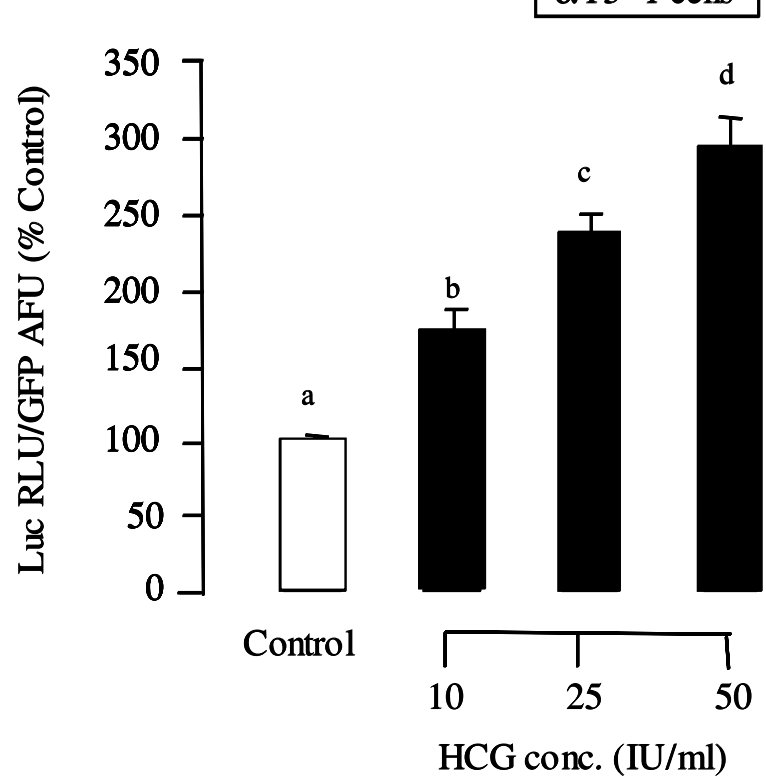

(B)

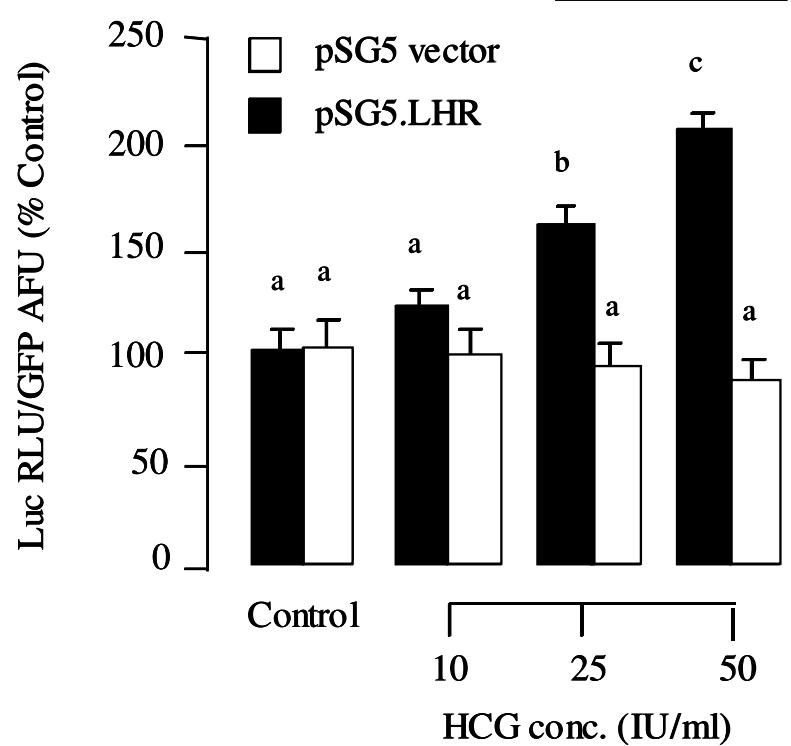

Figure 9 Effects of hCG on grass carp GH promoter activity. Co-transfection of luciferase-expressing pGH(-986). Luc with pcDNA.gcPit- 1 and pSG5.LHR was conducted in $\alpha$ T3-1 cells (A) and $\mathrm{GH} 4 \mathrm{C} 1$ cells (B) respectively. After transfection, cell cultures were exposed to increasing doses of hCG $(10-50$ $\mathrm{IU} / \mathrm{ml}$ ) for $24 \mathrm{~h}$. In the experiments with $\mathrm{GH} 4 \mathrm{C} 1$ cells, transfection with the blank vector pSG5 (without LHR insert) was used as a parallel control. Data presented (means \pm S.E.M., $n=8$ ) are pooled results from eight experiments (each with triplicate treatments). Treatment groups denoted by different letters represent a significant difference at $P<0.05$ (ANOVA followed by Fisher's LSD test).
(A)

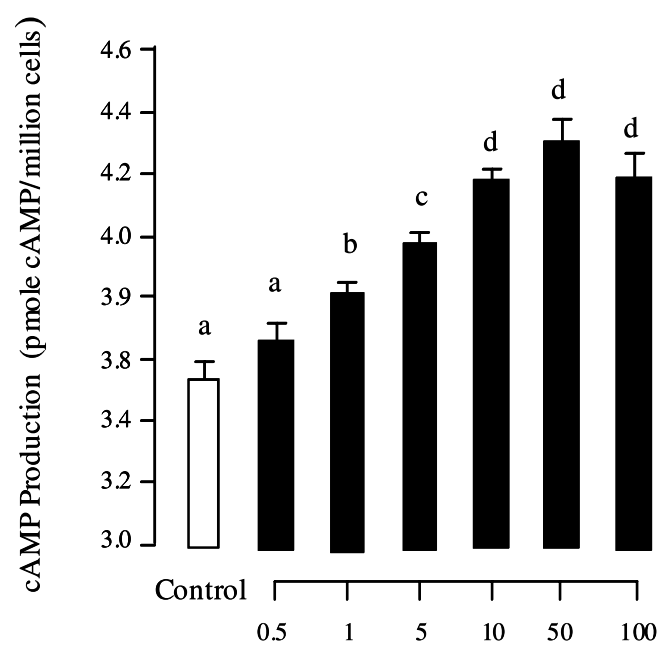

HCG concentration (IU/ml)

(B)
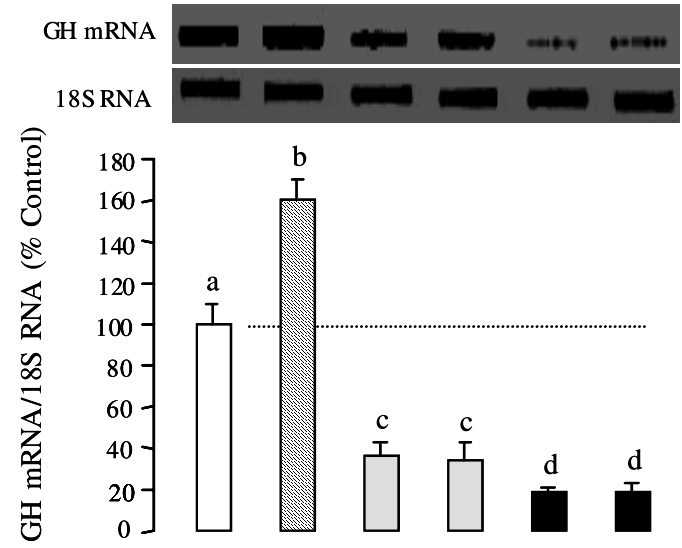

HCG (IU/ml) : $\begin{array}{lllllll}0 & 40 & 0 & 40 & 0 & 40\end{array}$

$\mathrm{H} 89(\mu \mathrm{M}) \quad: \quad \begin{array}{llllll}0 & 0 & 20 & 20 & 0 & 0\end{array}$

$\operatorname{MDL12330A}(\mu \mathrm{M}) \quad: \quad \begin{array}{lllllll}0 & 0 & 0 & 0 & 20 & 20\end{array}$

Figure 10 Functional role of the CAMP-dependent pathway in hCG-stimulated GH mRNA expression. (A) Effects of hCG on cAMP production in grass carp pituitary cells. Pituitary cells were incubated with increasing concentrations of hCG (0.5 $100 \mathrm{IU} / \mathrm{ml})$ for $20 \mathrm{~min}$ in the presence of IBMX $(0.1 \mathrm{mM})$. After that, culture medium was harvested for measurement of cAMP release and pituitary cells were extracted with ethanol for determination of cellular CAMP content. Total cAMP production was defined as the sum of CAMP release and cellular CAMP content. (B) Effects of inhibiting adenylate cyclase (AC) and protein kinase $\mathrm{A}$ (PKA) on hCG-stimulated GH mRNA expression in grass carp pituitary cells. Pituitary cells were exposed to the AC inhibitor, MDL12330A $(20 \mu \mathrm{M})$ or the PKA inhibitor, H89 $(20 \mu \mathrm{M})$ in the presence or absence of hCG $(40$ $\mathrm{IU} / \mathrm{ml}$ ) for $48 \mathrm{~h}$. In these experiments, the inhibitors were added $10 \mathrm{~min}$ prior to the initiation of hCG treatment. Data presented (means \pm S.E.M., $n=8$ ) are pooled results from eight experiments (each with triplicate treatments). Treatment groups denoted by different letters represent significant difference at $P<0.05$ (ANOVA followed by Fisher's LSD test). 


\section{(A)}

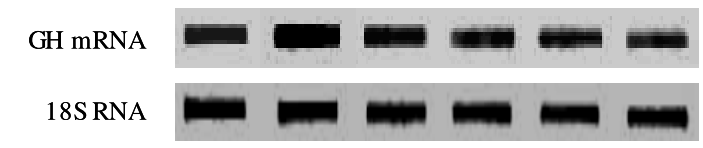

产 200
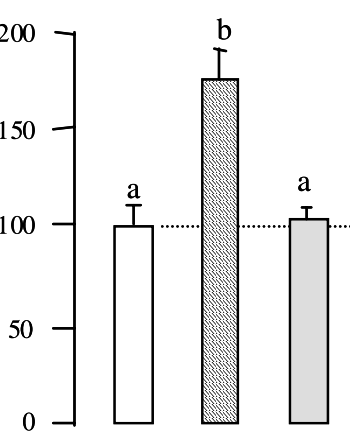

\begin{abstract}
HCG $(\mathrm{IU} / \mathrm{ml})$ : 0
$\operatorname{PD} 98059(\mu \mathrm{M}): 0$
\end{abstract}

Wortmannin $(\mathrm{nM}): 0$

(B)

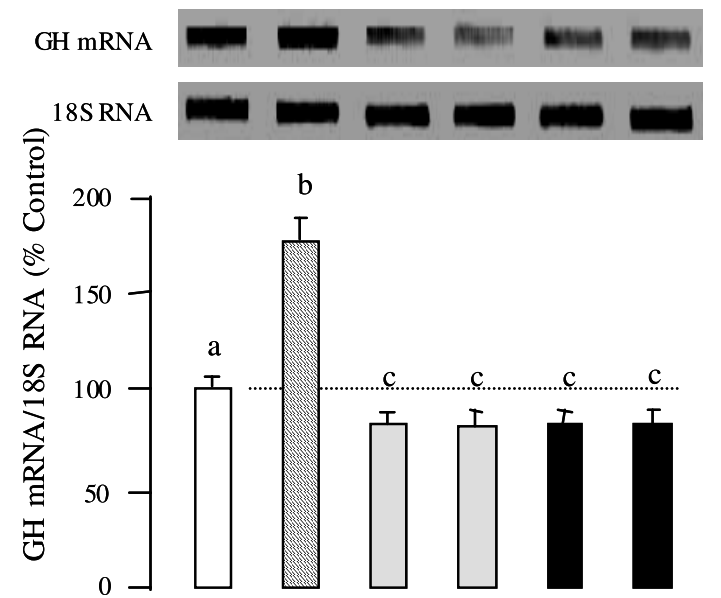

$\begin{array}{rrrrrrr}\mathrm{HCG}(\mathrm{IU} / \mathrm{ml}): & 0 & 40 & 0 & 40 & 0 & 40 \\ \mathrm{AG} 490(\mu \mathrm{M}): & 0 & 0 & 100 & 100 & 0 & 0 \\ \mathrm{SB} 202190(\mu \mathrm{M}): & 0 & 0 & 0 & 0 & 20 & 20\end{array}$

Figure 11 Effects of inhibiting MAPK and PI3K on hCG-stimulated GH mRNA expression. Grass carp pituitary cells were incubated for $48 \mathrm{~h}$ with $(\mathrm{A})$ the P42/44MAPK inhibitor, PD98059 $(100 \mu \mathrm{M})$ and the PI3K inhibitor, wortmannin $(100 \mathrm{nM})$, or (B) the JAK2 inhibitor, AG490 $(100 \mu \mathrm{M})$ and the P38MAPK inhibitor, SB202190 $(20 \mu \mathrm{M})$ in the presence or absence of hCG $(40 \mathrm{IU} / \mathrm{ml})$. In these studies, the inhibitors were added $10 \mathrm{~min}$ prior to the initiation of hCG treatment. Data presented (means \pm S.E.M., $n=8$ ) are pooled results from eight experiments (each with triplicate treatments). Treatment groups denoted by different letters represent a significant difference at $P<0.05$ (ANOVA followed by Fisher's LSD test).

grass carp pituitary cells were increased by GnRH, PACAP and APO, confirming that these GH secretagogues can activate GH gene expression in grass carp. The stimulatory effects of these GH secretagogues, except for
GnRH, were additive to that of hGG. Since the doses of GnRH, PACAP and APO tested have been shown to induce the maximal responses in GH mRNA expression in carp pituitary cells ( $\mathrm{Li}$ et al. 2000), the additivity observed in this study may imply that the stimulatory actions of APO and PACAP are independent of hCG. This is unexpected as LH receptors (Laan et al. 2002), Dl receptors (Wong et al. 1994) and PAC-I receptors (Wong et al. 1998b) are coupled to the AC/cAMP/PKA pathway in fish models. Although a differential transportation of cAMP to specific subcellular organelles/compartments has been reported in fibroblast cell lines (Scott \& Carr 1992), it is unclear if functional segregation of cAMP-dependent mechanisms also exists in fish by differential coupling to membrane receptors.

Unlike APO and PACAP, the stimulatory action of GnRH on GH mRNA expression was not enhanced by hCG treatment. Given that $\mathrm{GnRH}$ is a potent stimulator of LH release in fish models (Chang et al. 2000), the stimulatory action of hCG might have been masked by endogenous LH released in response to $\mathrm{GnRH}$ treatment. These results have prompted us to speculate that at least a part of the GnRH-induced GH gene expression is mediated through local secretion of LH in grass carp pituitary cells. In parallel experiments, the stimulatory effects of GnRH, PACAP and APO on GH mRNA expression were suppressed in a dose-dependent manner by $\mathrm{LH}$ antiserum. These results indicate that the sensitivity of carp somatotrophs to stimulation by these GH-releasing factors is dependent on the presence of endogenous LH. This may be related to the novel function of LH in maintaining GH synthesis in carp pituitary cells. In this case, the releasable pool of secretory vesicles for $\mathrm{GH}$ might have been markedly reduced in the absence of endogenous LH and therefore the cells became less responsive/non-responsive to GH-releasing factors. Alternatively, LH may play a role in regulating receptor expression for these GH-releasing factors. In the rat, hCG but not FSH suppresses the levels of GnRH receptor transcripts in the testes (Botte et al. 1999). In the same animal model, variations in dopamine receptor levels have been reported in the pituitary during different phases of the oestrous cycle (Zabavnik et al. 1993), which may be related to $17 \beta$-oestradiol production by the ovary under the influence of LH and FSH (Guivarc'h et al. 1998). Although PAC-I receptors have been implicated in the control of GnRH, GnRH receptor and LH $\beta$-subunit expression in the brain-pituitary axis (Choi et al. 2000), to our knowledge, no information is available regarding the role of LH in regulating PAC-I receptor expression. It is also worth mentioning that a higher level of LH antiserum (1:5000) was required to block APO-induced GH mRNA expression when compared with the dose (1:10 000) used in GnRH and PACAP stimulation. Since dopamine is known to inhibit LH release in 
fish via pituitary D2 receptors (Chang et al. 2000), the lower sensitivity of APO-induced GH gene expression to LH immunoneutralization might reflect a lower level of endogenous LH in pituitary cell cultures after dopaminergic stimulation.

To elucidate the molecular mechanisms for LHinduced GH gene expression at the pituitary level, the possible involvement of GH mRNA stability and GH gene transcription were examined. Clearance analysis of GH transcripts was conducted in carp pituitary cells in the presence of the transcription inhibitor, actinomycin D. This approach has been used in mammals to estimate the $T_{1 / 2}$ of target mRNA and has proved to be useful in

(A)
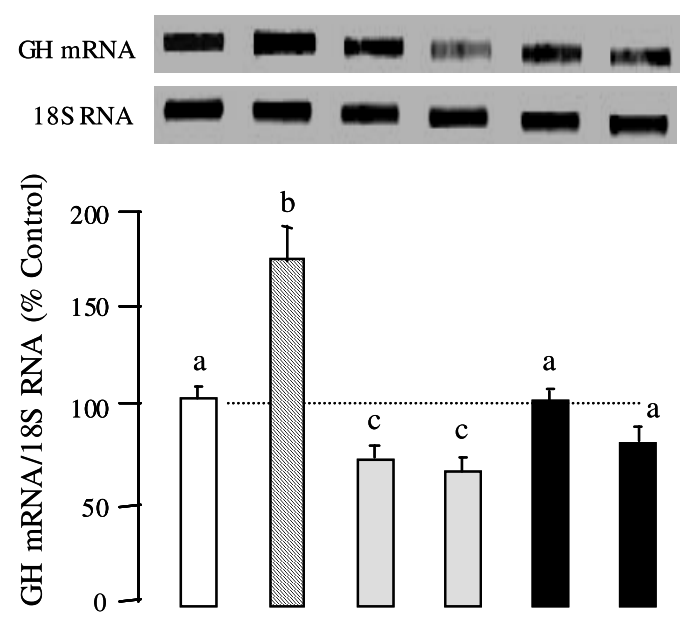

(B)
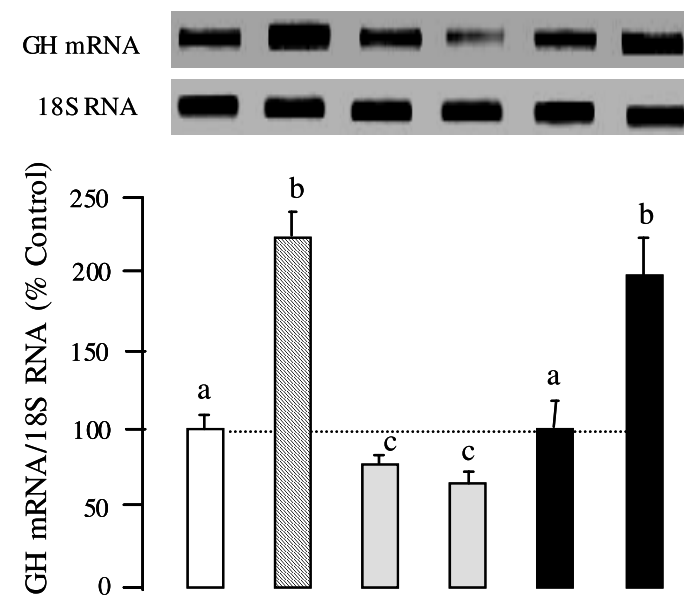

Forskolin $(\mu \mathrm{M}): 0$

$\mathrm{AG} 490(\mu \mathrm{M}): 0$

Wortmannin (nM) : 0 fish to study GH mRNA stability (Melamed et al. 1996). In grass carp pituitary cells treated with actinomycin D, the clearance rate of GH mRNA (as indicated by the $\mathrm{T}_{1 / 2}$ values) was not affected by hCG treatment. The clearance curve, however, was shifted to the right with an increase in $\mathrm{T}_{1 / 2}$ by $\mathrm{LH}$ immunoneutralization. These results indicate that the stability of GH mRNA was enhanced following the removal of endogenous LH. Apparently, LH can act at the pituitary level to promote GH mRNA degradation. The lack of hCG effect on GH mRNA clearance may also suggest that this novel action might have been saturated by basal release of $\mathrm{LH}$ in carp pituitary cells. To examine the possible role of GH gene transcription in LH-stimulated GH synthesis, real-time PCR was conducted to monitor the expression of GH primary transcripts. To serve as a parallel control, the level of mature GH mRNA was also measured in these experiments. In this study, mature GH mRNA and primary transcripts were reduced in a dose-dependent manner by LH antiserum. Since primary transcripts are processed rapidly and translocated to the cytoplasm as mature mRNA, the level of primary transcripts present in the nucleus is, in general, accepted to be a faithful reflection of target gene transcription (Beyersmann 2000). This idea is also consistent with the observation that hCG was effective in stimulating grass carp GH gene promoter activity in $\alpha \mathrm{T} 3-1$ cells (via mammalian LH receptors) and GH4C1 cells (via fish LH receptors). These results, as a whole, suggest that LH is essential in maintaining basal levels of GH gene transcription. Since LH removal could enhance the stability of GH transcripts, the concurrent drop in mature GH mRNA and GH primary transcripts may indicate that steady-state GH mRNA is primarily determined by GH gene transcription. In this study, two opposing effects of LH have been demonstrated, namely the stimulatory actions on (i) GH gene transcription and (ii) GH mRNA degradation. The combined actions of these two mechanisms may result in a rapid turnover of GH transcripts in grass carp pituitary cells.

At the gonadal level, $\mathrm{LH}$ receptors are essential for steroidogenesis and their stimulatory actions are mediated through functional coupling to Gs and

Figure 12 Effects of inhibiting MAPK and PI3K on forskolin-induced GH mRNA expression. Grass carp pituitary cells were incubated for $48 \mathrm{~h}$ with $(\mathrm{A})$ the P42/44MAPK inhibitor, PD98059 $(100 \mu \mathrm{M})$ and the P38MAPK inhibitor, SB202190 $(20 \mu \mathrm{M})$ or $(\mathrm{B})$ the JAK2 inhibitor, AG490 $(100 \mu \mathrm{M})$ and the $\mathrm{PI3K}$ inhibitor, wortmannin $(100 \mathrm{nM})$ in the presence or absence of forskolin $(10 \mu \mathrm{M})$. In these experiments, the inhibitors were added 10 min prior to the initiation of hCG treatment. Data presented (means \pm S.E.M., $n=8$ ) are pooled results from eight experiments (each with triplicate treatments). Treatment groups denoted by different letters represent a significant difference at $P<0.05$ (ANOVA followed by Fisher's LSD test). 
subsequent activation of the AC/cAMP/PKA pathway (Ascoli et al. 2002). Recently, functional coupling of LH receptors to MAPK- and PI3K-dependent mechanisms has also been reported in granulosa cells (Salvador $e t$ al. 2002) and Leydig cells (Hirakawa et al. 2002). In this study, hGG treatment not only elevated steady-state GH mRNA levels but also increased cAMP production in carp pituitary cells. Furthermore, hCG-induced GH mRNA expression was mimicked by the AC activator, forskolin but blocked by the AC inhibitor, MDL12330A and the PKA inhibitor, H89. These results confirm that LH receptors expressed in carp pituitary cells are functionally coupled to the AC/cAMP/PKA pathway. Given that basal GH mRNA levels were markedly suppressed by AC and PKA inhibition, the cAMPdependent cascade may represent a key component maintaining resting state $\mathrm{GH}$ gene expression in Chinese grass carp. This idea is consistent with the finding that the $5^{\prime}$ promoters of $\mathrm{GH}$ gene, e.g. human GH gene (Shepard et al. 1994), are known to contain cis-acting elements responsive to cAMP stimulation (e.g. CRE). In fish, e.g. chinook salmon, cAMP induction of GH gene transcription is mediated by two CGTCA motifs in the 5' proximal promoter (Wong et al. 1996).

Besides the cAMP-dependent cascade, hCG-induced GH gene expression in grass carp may also involve other signalling components. In this case, the MAPK inhibitors, namely PD98059 for P42/44 MAPK and SB202190 for P38 ${ }^{\mathrm{MAPK}}$, were effective in blocking hCGand forskolin-stimulated GH mRNA expression, suggesting that $\mathrm{P} 42 / 44^{\mathrm{MAPK}}$ and P38 MAPK may be functionally coupled to the cAMP-dependent pathway to modulate GH gene expression in carp pituitary cells. In mammals, functional coupling of P42/44 MAPK to LH receptors through PKA phosphorylation of Raf-1/C-Raf (Dhillon et al. 2002) and B-Raf (Qiu et al. 2000) has been reported. P42/44 ${ }^{\mathrm{MAPK}}$ can also be activated independent of PKA by direct actions of cAMP on the Rap- 1 guanine nucleotide-exchange factor Epac (Enserink et al. 2002). Although the coupling of P38 ${ }^{\mathrm{MAPK}}$ with LH receptors through cAMP-dependent mechanisms has not been reported, PKA-dependent activation/ phosphorylation of $\mathrm{P} 38^{\mathrm{MAPK}}$ has been demonstrated in mouse cardiomyocytes (Zheng et al. 2000). It is worth mentioning that hCG- and forskolin-induced GH mRNA expression in carp pituitary cells were totally abolished by the JAK2 inhibitor, AG490. These results were unexpected as AG490 was used as a negative control in these experiments. The inhibitory action of AG490 may suggest that pituitary LH receptors can recruit JAK2 as a downstream effector for the $\mathrm{AC} / \mathrm{cAMP} / \mathrm{PKA}$ pathway. JAK2 is a non-receptor tyrosine kinase coupled to cytokine receptors (Kisseleva et al. 2002) and the present finding of its involvement in hCG-induced GH gene expression raises the possibility that LH receptors may activate $\mathrm{P} 42 / 44^{\mathrm{MAPK}}$ indirectly via the JAK2/Grb2/SOS/Ras/Raf/MEK pathway. After ligand binding to $G$ protein-coupled receptors, e.g. $\mu$ opioid receptors (Ai et al. 1999), PI3K has been shown to act as a mediator for P42/44 ${ }^{\mathrm{MAPK}}$ activation by cross-talk at the level of protein kinases. However, the possible existence of a similar mechanism in hGGinduced GH gene expression in grass carp pituitary cells is unlikely as the PI3K inhibitor, wortmannin, was only effective in blocking hCG- but not forskolin-induced GH mRNA expression. These results indicate that PI3K mediates hCG stimulation of GH gene expression but it is not coupled to the cAMP-dependent pathway or the downstream MAPK cascades. Apparently, multiple signalling pathways (both cAMP-dependent and cAMPindependent) are associated with pituitary LH receptors, which may be functional in fine-tuning $\mathrm{LH}$-induced $\mathrm{GH}$ gene expression in the carp model.

In summary, using grass carp pituitary cells as a model, we have demonstrated for the first time that LH can act in a paracrine manner at the pituitary level to regulate basal GH secretion, GH gene expression, and somatotroph responsiveness to GH-releasing factors. The paracrine actions of LH on GH mRNA expression are mediated by a concurrent increase in GH gene transcription and GH transcript turnover. Furthermore, we also speculate that (i) the JAK2/MAPK cascades secondary coupled to the cAMP-dependent pathway and (ii) the PI3K cascade independent of cAMPmediated mechanisms may be the key elements in the signal transduction for LH-induced GH gene expression. The present study not only provides new insights into the paracrine regulation of $\mathrm{GH}$ synthesis and secretion at the pituitary level, but also sheds light on a novel mechanism for functional interactions between the gonadotrophic and somatotrophic axes. The phenomenon described in the present study may also explain the evolution of a close anatomical relationship between gonadotrophs and somatotrophs in teleosts and accounts for the parallel changes in $\mathrm{LH}$ and $\mathrm{GH}$ secretion in fish during sexual recrudescence and the spawning season.

\section{Acknowledgements}

The present study was sponsored by RGC (HK) and CRCG grants (HKU) to A O L W. Financial support from the Department of Zoology (HKU) to H Z and Y J in the form of postgraduate studentships is also acknowledged. Special thanks are given to Drs R E Peter and J P Chang (University of Alberta, Canada) for the supply of antisera for immunoneutralization and Dr Y Nagahama (National Institute for Basic Research, Japan) for the supply of the salmon LH receptor expression vector pSG5.LHR. We are also indebted to Dr W W M Lee (Zoology, HKU) for his support in setting up the 
real-time PGR system for the measurement of $\mathrm{GH}$ primary transcripts.

\section{References}

Ai W, Gong J \& Yu L 1999 MAP kinase activation by $\mu$ opioid receptor involves phosphatidylinositol 3-kinase but not the cAMP/PKA pathway. FEBS Letters 456 196-200.

Argente J, Chowen-Breed JA, Steiner RA \& Clifton DK 1990 Somatostatin messenger RNA in hypothalamic neurons is increased by testosterone through activation of androgen receptors and not by aromatization to estradiol. Neuroendocrinology $\mathbf{5 2}$ 342-349.

Ascoli M, Fanelli F \& Segaloff DL 2002 The lutropin/ choriogonadotropin receptor, a 2002 perspective. Endocrine Review 23 141-174.

Beyersmann D 2000 Regulation of mammalian gene expression. Toxicology Letters 127 63-68.

Botte MC, Lerrant Y, Lozach A, Berault A, Counis R \& Kottler ML 1999 LH down-regulates gonadotropin-releasing hormone (GnRH) receptor but not GnRH mRNA levels in the rat testis. Fournal of Endocrinology 162 409-415.

Carvalho CR, Carvalheira JB, Lima MH, Zimmerman SF, Caperuto LC, Amanso A, Gasparetti AL, Meneghetti V, Zimmerman LF, Velloso LA et al. 2003 Novel signal transduction pathway for luteinizing hormone and its interaction with insulin: activation of Janus kinase/signal transducer and activator of transcription and phosphoinositol 3-kinase/Akt pathways. Endocrinology 144 638-647.

Chandrashekar V \& Bartke A 1998 The role of growth hormone in the control of gonadotropin secretion in adult male rats. Endocrinology 139 1067-1074.

Chang JP, Johnson JD, Van Goor F, Wong GJ, Yunker WK, Uretsky AD, Taylor D, Jobin RM, Wong AOL \& Goldberg JI 2000 Signal transduction mechanisms mediating secretion in goldfish gonadotropes and somatotropes. Biochemistry and Cell Biology 78 139-153.

Choi EJ, Ha CM, Kim MS, Kang JH, Paek SK, Choi WS, Kang SG \& Lee BJ 2000 Central administration of an antisense oligodeoxynucleotide against type I pituitary adenylate cyclase-activating polypeptide receptor suppresses synthetic activities of LHRH-LH axis during the pubertal process. Molecular Brain Research 80 35-45.

Cook H, Berkenbosch JW, Fernhout MJ, Yu KL, Peter RE, Chang JP \& Rivier JE 1991 Demonstration of gonadotropin releasinghormone receptors on gonadotrophs and somatotrophs of the goldfish: an electron microscope study. Regulatory Peptides $\mathbf{3 6}$ 369-378.

Dhillon AS, Pollock C, Steen H, Shaw PE, Mischak H \& Kolch W 2002 Cyclic AMP-dependent kinase regulates Raf-1 kinase mainly by phosphorylation of serine 259. Molecular and Cellular Biology 22 3237-3246.

Doerr-Schott J 1980 Immunohistochemistry of the adenohypophysis of non-mammalian vertebrates. Acta Histochemica (Suppl) 22 $185-223$

Enserink JM, Christensen AE, de Rooij J, van Triest M, Schwede F, Genieser HG, Doskeland SO, Blank JL \& Bos JL 2002 A novel Epac-specific cAMP analogue demonstrates independent regulation of Rapl and ERK. Nature Cell Biology 4 901-906.

Ge W \& Peter RE 1994 Activin-like peptides in somatotrophs and activin stimulation of growth hormone release in goldfish. General and Comparative Endocrinology 95 213-221.

Guivarc'h D, Vincent JD \& Vernier P 1998 Alternative splicing of the D2 dopamine receptor messenger ribonucleic acid is modulated by activated sex steroid receptors in the MMQ prolactin cell line. Endocrinology 139 4213-4221.

Harvey S, Baumbach WR, Sadeghi H \& Sanders EJ 1993 Ultrastructural colocalization of growth hormone binding protein and pituitary hormones in adenohypophyseal cells of the rat. Endocrinology 133 1125-1130.

Hirakawa T, Galet C \& Ascoli M 2002 MA-10 cells transfected with the human lutropin/choriogonadotropin receptor (hLHR): a novel experimental paradigm to study the functional properties of the hLHR. Endocrinology 143 1026-1035.

Hull KL \& Harvey S 2000a Growth hormone: roles in male reproduction. Endocrine 13 243-250.

Hull KL \& Harvey S $2000 b$ Growth hormone: a reproductive endocrine/paracrine regulator? Reviewes of Reproduction $\mathbf{5}$ $175-182$.

Hull KL \& Harvey S 2002 GH as a co-gonadotropin: the relevance of correlative changes in $\mathrm{GH}$ secretion and reproductive state. Fournal of Endocrinology 172 1-19.

Ieiri T, Ishikawa K, Suzuki M \& Shimoda S 1988 Growth hormone synthesis decreased after anterolateral deafferentation of the medial basal hypothalamus in the rat. Neuroendocrinology 47 $431-436$

Kagawa H, Kawazoe I, Tanaka H \& Okuzawa K 1998 Immunocytochemical identification of two distinct gonadotropins (GTH I and GTH II) in the pituitary of bluefin tuna, Thunnus thynnus. General and Comparative Endocrinology 110 11-18.

Kerrigan JR \& Rogol AD 1992 The impact of gonadal steroid hormone action on growth hormone secretion during childhood and adolescence. Endocrine Reviews 13 281-298.

Kisseleva T, Bhattacharya S, Braunstein J \& Schindler CW 2002 Signaling through the JAK/STAT pathway, recent advances and future challenges. Gene 285 1-24.

Laan M, Richmond H, He C \& Campbell RK 2002 Zebrafish as a model for vertebrate reproduction: characterization of the first functional zebrafish (Danio rerio) gonadotropin receptor. General and Comparative Endocrinology 125 349-364.

LeGac FBO, Fostier A, LeBail P-Y, Loir M, Mourot B \& Weil G 1993 Growth hormone $(\mathrm{GH})$ and reproduction: a review. Fish Physiology and Biochemistry 11 219-232.

Lei ZM, Rao GV, Kornyei JL, Licht P \& Hiatt ES 1993 Novel expression of human chorionic gonadotropin/luteinizing hormone receptor gene in brain. Endocrinology 132 2262-2270.

Li WS, Chu MMS, Lin HR \& Wong AOL 2000 Interactions of pituitary adenylate cyclase activating polypeptide with gonadotropin- releasing hormone, dopamine, and somatostatin in regulating growth hormone gene expression in grass carp pituitary cells. In Program and Abstracts, 4th International Symposium on Fish Endocrinology, Seattle (USA) p 45. Abstract no. ISFE W-528.

Li WS, Lin HR \& Wong AOL 2002 Effects of gonadotropin-releasing hormone on growth hormone secretion and gene expression in common carp pituitary. Comparative Biochemistry and Physiology B 132 335-341.

Lin XW, Lin HR \& Peter RE 1993 Growth hormone and gonadotropin secretion in the common carp (Cyprinus carpio L.): in vitro interactions of gonadotropin-releasing hormone, somatostatin, and the dopamine agonist apomorphine. General and Comparative Endocrinology $8962-71$.

Meiri I, Knibb WR, Zohar Y \& Elizur A 2004 Temporal profile of $\beta$ follicle-stimulating hormone, $\beta$ luteinizing hormone, and growth hormone gene expression in protandrous hermaphrodite, gilthead seabream (Sparus aurata). General and Comparative Endocrinology 137 288-299.

Melamed P, Gur G, Elizur A, Rosenfeld H, Sivan B, Rentier-Delrue F \& Yaron Z 1996 Differential effects of gonadotropin-releasing hormone, dopamine and somatostatin and their second messengers on the mRNA levels of gonadotropin II beta subunit and growth hormone in the teleost fish, tilapia. Neuroendocrinology $64320-328$. 
Montero M, Yon L, Kikuyama S, Dufour S \& Vaudry H 2000 Molecular evolution of the growth hormone-releasing hormone/pituitary adenylate cyclase-activating polypeptide gene family. Functional implication in the regulation of growth hormone secretion. Fournal of Molecular Endocrinology 25 $157-168$.

Peter RE \& Yu KL 1997 Neuroendocrine regulation of ovulation in fishes: basic and applied aspects. Reviewes in Fish Biology and Fisheries 7 173-197.

Peter RE, Yu KL, Marchant TA \& Rosenblum PM 1990 Direct neural regulation of the adenohypophysis. Fournal of Experimental Zoology 4 84-89.

Qiu W, Zhuang S, von Lintig FC, Boss GR \& Pilz RB 2000 Cell type-specific regulation of B-Raf kinase by cAMP and 14-13-3 proteins. Fournal of Biological Chemistry 275 31921-31929.

Rao CV 2001 Multiple novel roles of luteinizing hormone. Fertility and Sterility 76 1097-1100.

Salvador LM, Maizels E, Hales DB, Miyamoto E, Yamamoto H \& Hunzicker-Dunn M 2002 Acute signaling by the LH receptor is independent of protein kinase C activation. Endocrinology 143 2986-2994.

Schemm SR, Deaver DR, Griel LC Jr \& Muller LD 1990 Effects of recombinant bovine somatotropin on luteinizing hormone and ovarian function in lactating dairy cows. Biology of Reproduction $\mathbf{4 2}$ 815-821.

Schwartz J 2000 Intercellular communication in the anterior pituitary. Endocrine Reviewes 21 488-513.

Scott JD \& Carr DW 1992 Subcellular localization of the type II cAMP-dependent protein-kinase. Nerws in Physiological Sciences 7 143-148.

Seger R, Hanoch T, Rosenberg R, Dantes A, Merz WE, Strauss JF 3rd \& Amsterdam A 2001 The ERK signaling cascade inhibits gonadotropin-stimulated steroidogenesis. Fournal of Biological Chemistry 276 13957-13964.

Shepard AR, Zhang W \& Eberhardt NL 1994 Two CGTCA motifs and a GHF1/Pitl binding site mediate cAMP-dependent protein kinase A regulation of human growth hormone gene expression in rat anterior pituitary GC cells. Fournal of Biological Chemistry 269 1804-1814.

Stacey NE, MacKenzie DS, Marchant TA, Kyle AL \& Peter RE 1984 Endocrine changes during natural spawning in the white sucker, Catostomus commersoni. I. Gonadotropin, growth hormone, and thyroid hormones. General and Comparative Endocrinology $\mathbf{5 6}$ 333-348.

Tang K, Bartke A, Gardiner CS, Wagner TE \& Yun JS 1993 Gonadotropin secretion, synthesis, and gene expression in two types of bovine growth hormone transgenic mice. Biology of Reproduction 49 346-353.

Wit JM, Massarano AA, Kamp GA, Hindmarsh PC, Van Es A, Brook CG, Preece MA \& Matthews DR 1992 Growth hormone secretion in patients with Turner's syndrome as determined by time series analysis. Acta Endocrinologica 127 7-12.

Wong AOL, Chang JP \& Peter RE 1993a Characterization of D1 receptors mediating dopamine-stimulated growth hormone release from pituitary cells of the goldfish, Carassius auratus. Endocrinology 133 577-584.

Wong AOL, Chang JP \& Peter RE $1993 b$ Interactions of somatostatin, gonadotropin releasing hormone, and the gonads on dopamine-stimulated growth hormone release in the goldfish. General and Comparative Endocrinology 92 366-378.
Wong AOL, van der Kraak G \& Chang JP 1994 Cyclic $3^{\prime}, 5^{\prime}$-adenosine monophosphate mediates dopamine D1-stimulated growth hormone release from goldfish pituitary cells. Neuroendocrinology $60410-417$.

Wong AOL, Le Drean Y, Liu D, Hu ZZ, Du SJ \& Hew CL 1996 Induction of chinook salmon growth hormone promoter activity by the adenosine $3^{\prime}, 5^{\prime}$-monophosphate (cAMP)-dependent pathway involves two cAMP-response elements with the CGTCA motif and the pituitary-specific transcription factor Pit-1. Endocrinology 137 1775-1784.

Wong AOL, Ng S, Lee EK, Leung RC \& Ho WK 1998 a Somatostatin inhibits (D-Arg ${ }^{6}$, Pro $^{9} \mathrm{NEt}$ ) salmon gonadotropin-releasing hormone- and dopamine D1-stimulated growth hormone release from perifused pituitary cells of Chinese grass carp, Ctenopharyngodon idellus. General and Comparative Endocrinology $11029-45$.

Wong AOL, Leung MY, Shea WL, Tse LY, Chang JP \& Chow BK $1998 b$ Hypophysiotropic action of pituitary adenylate cyclaseactivating polypeptide (PACAP) in the goldfish: immunohistochemical demonstration of PACAP in the pituitary, PACAP stimulation of growth hormone release from pituitary cells, and molecular cloning of pituitary type I PACAP receptor. Endocrinology 139 3465-3479.

Wong AOL, Li WS, Lee EK, Leung MY, Tse LY, Chow BK, Lin HR \& Chang JP 2000 Pituitary adenylate cyclase activating polypeptide as a novel hypophysiotropic factor in fish. Biochemistry and Cell Biology 78 329-343.

Wood DF, Docherty K, Ramsden DB \& Sheppard MC 1987 A comparison of the effects of bromocriptine and somatostatin on growth hormone gene expression in the rat anterior pituitary gland in vitro. Molecular and Cellular Endocrinology 52 257-261.

Wood JR \& Strauss III JF 2002 Multiple signal transduction pathways regulate ovarian steroidogenesis. Reviewes in Endocrine and Metabolic Disorders 3 33-46.

Yunker WK, Lee EKY, Wong AOL \& Chang JP 2000 Norepinephrine regulation of growth hormone release from goldfish pituitary cells. II. Intracellular sites of action. Fournal of Neuroendocrinology 12 323-333.

Zabavnik J, Wu WX, Eidne KA \& McNeilly AS 1993 Dopamine-D(2) receptor messenger-RNA in the pituitary during the estrous cycle, pregnancy and lactation in the rat. Molecular and Cellular Endocrinology 95 121-128.

Zeitler P, Argente J, Chowen-Breed JA, Clifton DK \& Steiner RA 1990 Growth hormone-releasing hormone messenger ribonucleic acid in the hypothalamus of the adult male rat is increased by testosterone. Endocrinology 127 1362-1368.

Zheng M, Zhang SJ, Zhu WZ, Ziman B, Kobilka BK \& Xiao RP $2000 \beta 2$-adrenergic receptor-induced p38 MAPK activation is mediated by protein kinase A rather than by Gi or G $\beta \gamma$ in adult mouse cardiomyocytes. Fournal of Biological Chemistry 275 40635-40640.

Zhou H, Ko WKW, Ho WKK, Stojikovic SS \& Wong AOL 2004 Novel aspects of growth hormone $(\mathrm{GH})$ autoregulation: GH-induced GH gene expression in grass carp pituitary cells through autocrine/paracrine mechanisms. Endocrinology 145 4615-4628.

Received 2 November 2004 Accepted 7 December 2004 